\title{
SEDIMENT VOLUME AND GRAIN-SIZE PARTITIONING BETWEEN SUBMARINE CHANNEL-LEVEE SYSTEMS AND LOBES: AN EXPERIMENTAL STUDY
}

\author{
JAN DE LEEUW, ${ }^{1,2}$ JORIS T. EGGENHUISEN, ${ }^{1}$ YVONNE T. SPYCHALA, ${ }^{1}$ MAARTEN S. HEIJNEN,${ }^{1,3}$ FLORIAN POHL, ${ }^{1}$ AND MATTHIEU J.B. \\ CARTIGNY ${ }^{4}$ \\ ${ }^{1}$ Faculty of Geosciences, Utrecht University, PO Box 80021, 3508TA Utrecht, The Netherlands \\ ${ }^{2}$ Division of Geological and Planetary Sciences, California Institute of Technology, MC 170-25, 1200 East California Boulevard, Pasadena, California 91125, U.S.A. \\ ${ }^{3}$ National Oceanography Centre, University of Southampton Waterfront Campus, Southampton SO14 3ZH, U.K. \\ ${ }^{4}$ Departments of Geography and Earth Sciences, Durham University, Durham DH1 3LY, U.K. \\ e-mail:leeuw.j.de@gmail.com
}

\begin{abstract}
The width and depth of submarine channels change progressively as the channels evolve. This is inferred to act as an important control on the rate of sediment loss due overbank and in-channel deposition. Understanding the downstream extraction of sediment from turbidity currents is important for the prediction of grain-size trends and volume distribution in the stratigraphy. However, the partitioning of sediment by individual turbidity currents as a function of channel dimensions has not been investigated previously. We present a series of physical experiments studying the link between channel dimensions and the resulting partitioning of sediment volume and grain size between sub-environments. The experimental set-up consists of a slope $\left(11^{\circ}\right)$ with a straight pre-formed channel and a horizontal basin floor. An identical flow was released repeatedly into channels with different dimensions, resulting in various styles of overspill, erosion, and deposition under varying degrees of channel confinement. The fraction of sediment that was bypassed through the channel to the basin floor varied between $67 \%$ and $89 \%$, depending on the amount of levee and in-channel deposition. The volume of levee deposition correlates well with channel depth. A large channel depth relative to flow thickness limits the amount of overspill. The amount of in-channel deposition correlates well with channel width/depth (W/D) ratio, where low-W/D-ratio channels have less deposition.

We compare the experiments to natural system to show that the same patterns of volume and grain-size partitioning are present at different scales. The experiments provide snapshots of different phases of evolution of natural submarine channels. Natural submarine channels in an early evolution phase are inferred to be shallow and the experiments demonstrate that this results in significant sediment loss to levee deposition along the channel. The process of levee deposition preferentially extracts the fine-grained sediment fraction, which overspills from the channel. Therefore, we predict that the initial sediment pulse that reaches the basin floor is coarse grained and volumetrically small. As the channel matures and deepens, it will bypass more sediment with a mix of grain sizes to the basin floor.
\end{abstract}

\section{INTRODUCTION}

Turbidity currents transport large volumes of sediment from the shelf edge into ocean basins through submarine channels over distances varying from tens to thousands of kilometers (Heezen and Ewing 1952; Damuth and Kumar 1975; Talling et al. 2012; Stevenson et al. 2013; Dorrell et al. 2014; Kneller et al. 2016). These channels can transfer the currents over large distances with limited exchange of sediment by deposition or erosion (Stevenson et al. 2013, 2015). Typically, however, there is some degree of in-channel and overbank deposition by turbidity currents, which leads to changes in volume and grain-size distribution of sediment transported in suspension. The remaining sediment in turbidity currents that reaches the downstream end of a channel is deposited as lobes. Size and composition of these lobes are thus controlled by the degree of sediment extraction in the upstream channel section. The analysis of sediment routing systems in a mass-balance framework has proven to be a valuable method to unravel the forcing mechanisms driving such coupled volume-grain-size trends.
Such an approach has already been applied to alluvial-coastal systems such as the Cretaceous infill of the Western Interior Basin (Hampson et al. 2014), the Eocene infill of the South Pyrenees Foreland Basin (Michael et al. 2014), to experimental fluvial systems (Strong et al. 2005), and a turbidite minibasin (Paola and Martin 2012).

Volumetric partitioning of sediment among different components of deep-water systems has been reconstructed at several locations. Straub et al. (2012) analyzed a channel system on the upper continental slope offshore Brunei (Fig. 1A, B) and found that levees form $89 \%$ of the channel-related stratigraphy while channel fills occupy $11 \%$. Paola and Martin (2012) studied a turbidite minibasin and found that channels occupied roughly $80 \%$ of the stratigraphic volume while terminal lobes formed the remaining $20 \%$ (Fig. 1C). Based on this, they speculated that the channel-lobe transition in deep-water systems may be controlled by the degree of mass extraction. Grain-size changes along the sediment-transport system have been shown to be intricately linked with this mass extraction. 

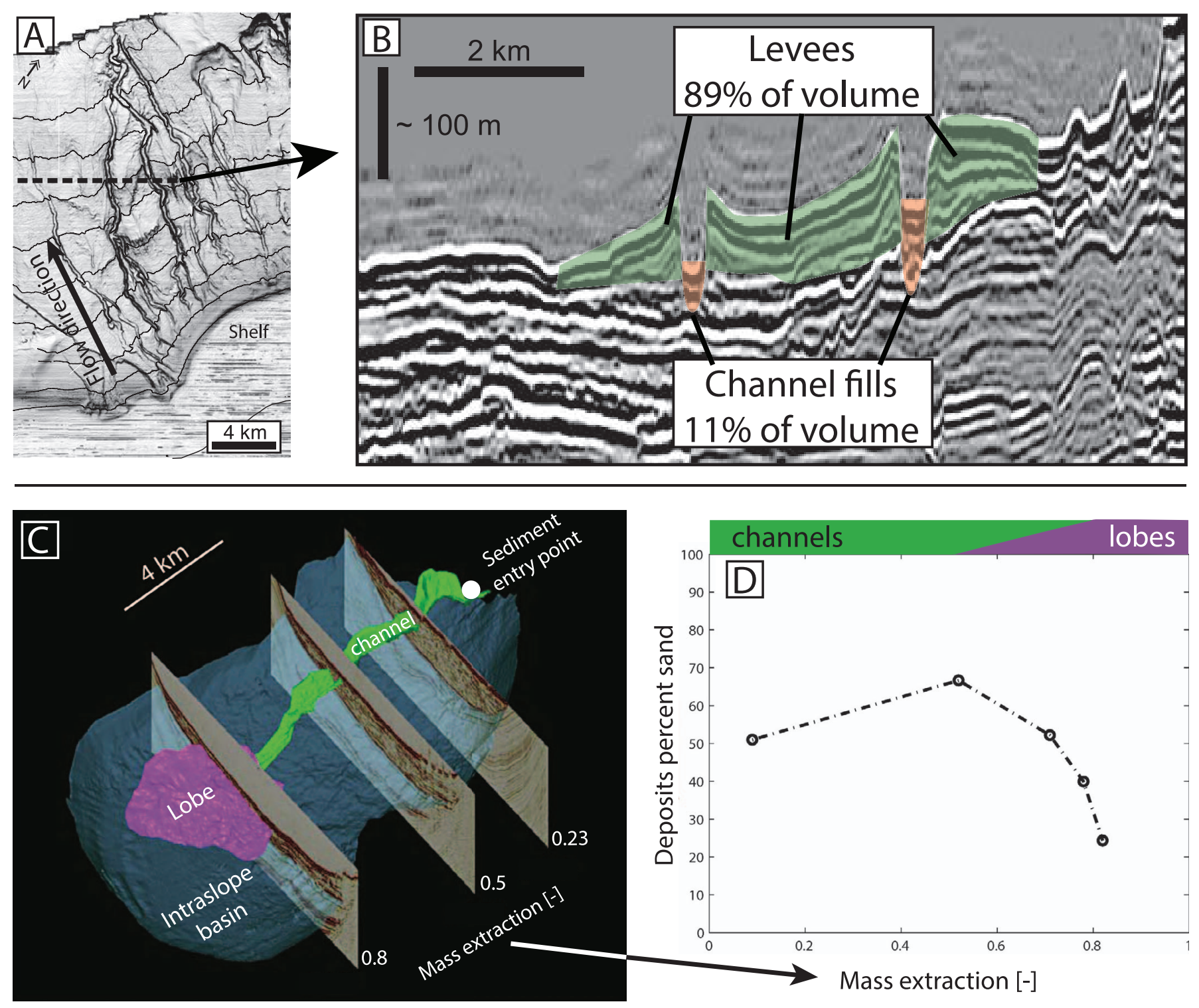

FIG. 1.-Volume estimates of depositional elements in deep-water systems. A, B) Partitioning of sediment volumes between channel fills and levees for a channel network on the continental slope offshore Brunei Darussalam (NW Borneo). Levees constitute a much greater volume than channel fills in this system. Figure modified after Straub et al. (2012). C) Partitioning of sediment volumes between channel-related deposits and lobe deposits in an intraslope minibasin that is part of the Brazos-Trinity slope system in the Gulf of Mexico. Parts B and C are modified after Paola and Martin (2012). D) Partitioning of sediment grain sizes in the same minibasin. Sand content of the deposits increases downstream in the channelized section of the basin. Sand content of the deposits decreases downstream in the section of the basin where lobes dominate.

The highest proportion of sand in the system studied by Paola and Martin (2012) is found around the start of the channel-lobe transition at a mass extraction of $50 \%$ (Fig. 1D). Similarly, the highest sand content in many other deep-water systems occurs in the basin-floor segment, where lobes are a major stratigraphic component (Prather et al. 2017).

In all of this previous work the relationship between turbidity-current characteristics (thickness, stratification) and channel dimensions is widely recognized as a key control on sediment partitioning in deep-water systems, yet no study has systematically and quantitatively explored the controlling parameters and demonstrated how flow-channel interactions modulate delivery of sediment mass and grain size to the basin floor.

Turbidity currents in leveed submarine channels can exchange sediment with their surroundings in various ways. Firstly, overspilling flows preferentially deposit fine-grained sediment on the levees (Hiscott et al. 1997; Posamentier and Kolla 2003; Kane et al. 2007; Hansen et al. 2015; de Leeuw et al. 2018). Secondly, deposition in the channel axis occurs when channels are aggradational, resulting in the extraction of the coarsergrained sediment fraction from the flow (Clark and Pickering 1996; Normark 1978). The volume and grain size of the mass extracted depend mainly on channel depth relative to flow height (Mohrig and Buttles 2007; de Leeuw et al. 2018). Typically, after channel inception, confinement increases progressively due to levee build-up and/or channel incision, and this increases channel efficiency (i.e., their ability to transport sediment basinwards (Hodgson et al. 2016)). The increased efficiency may cause the channel to extend, delivering more sediment to terminal lobes.

We apply a mass-balance approach to an experimental deep-water system consisting of a slope-channel segment and a horizontal basin floor. Physical experiments have the advantage that the sediment input is precisely constrained and it is possible to track the distribution of deposits from individual currents. The aims of this study are: (1) to investigate the 

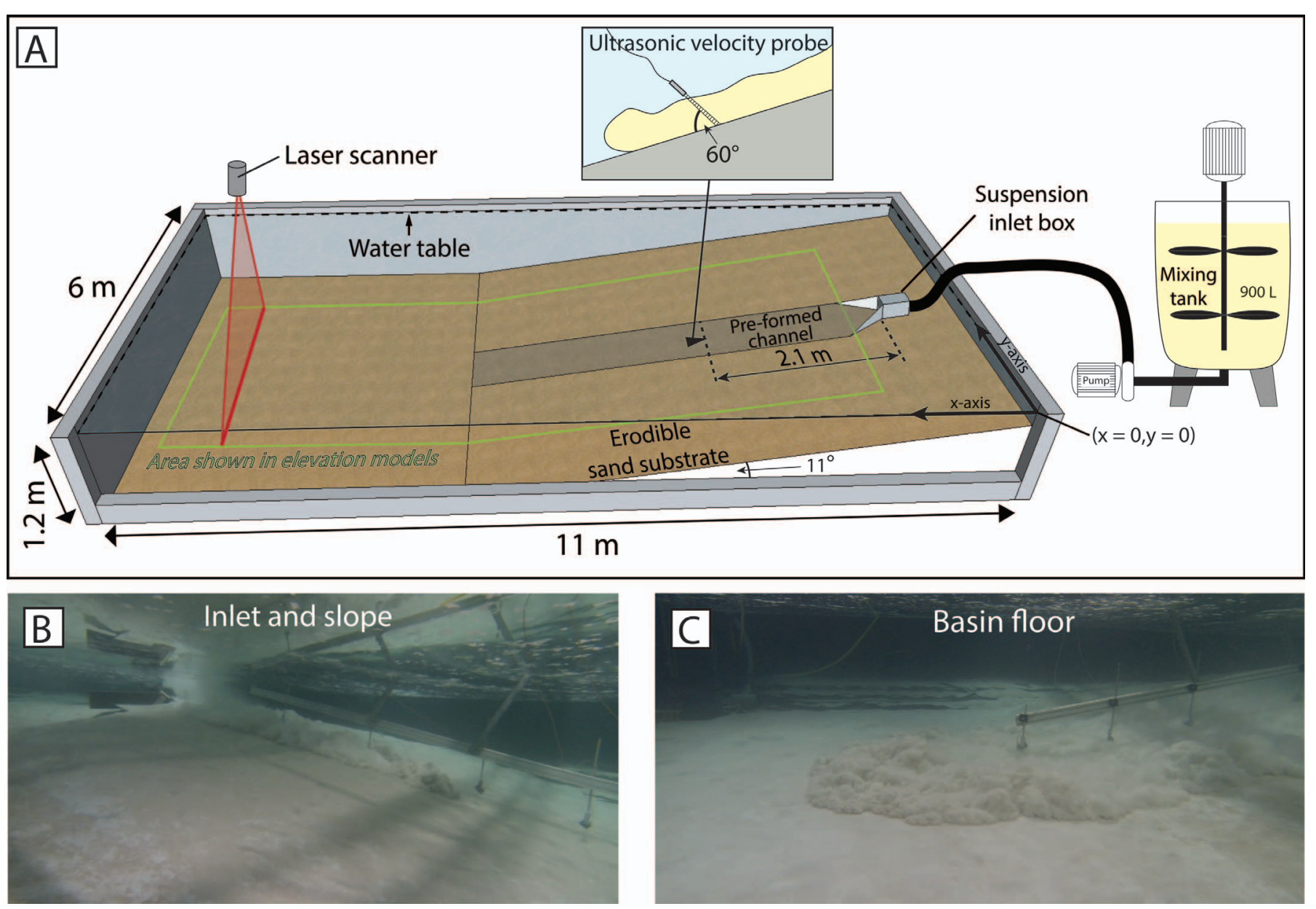

FIG. 2.-A) Set-up for flume experiments. A mixture of sediment and water is sourced from an external mixing tank. In the basin, the turbidity current flows over a slope with a pre-formed channel. The substrate is erodible. Current velocity is monitored with an ultrasonic velocity probe in the center of the channel at $2.1 \mathrm{~m}$ from the inlet. B, C) Images taken by underwater cameras taken from various viewpoints. The images show multiple velocity probes. We only use data from one velocity probe in this paper.

partitioning of sediment volumes and grain sizes among levees, channel fills, and lobes as a function of channel width and depth (together termed channel dimensions throughout this paper) in a controlled laboratory setting; (2) to reconstruct the flow evolution from the documented deposits; (3) to review published estimates of volume and grain-size partitioning in deep-water systems; and (4) to discuss the applications of our results towards stratigraphic prediction and interpretation.

\section{METHODS}

\section{Set-Up, Procedure, and Measurements}

We performed the experiments in a tank which is $11 \mathrm{~m}$ long, $6 \mathrm{~m}$ wide, and $1.2 \mathrm{~m}$ deep (Fig. 2A). The basin had a floor with a slope of $11^{\circ}$ with a

TABLE 1.-Boundary conditions that were identical for all of the experiments.

\section{Boundary Conditions}

\section{Suspension tank volume [L]}

Initial sediment concentration [\% vol.]

Discharge $[\mathrm{L} / \mathrm{s}]$

Slope angle $\left[^{\circ}\right]$

Basin-floor angle $\left[{ }^{\circ}\right]$ horizontal section at its base. All boundary conditions, except for channel dimensions, were identical for all experiments (Table 1). The entire basin floor was covered with a layer of erodible sand. A channel was carved in the slope before each experiment. Table 2 shows the depth and width of the pre-formed channel for each experiment. These dimensions were chosen based on the dimensions of a self-formed channel created in earlier experiments with similar boundary conditions (de Leeuw et al. 2016). The same procedure was followed during each of the experiments. First, the basin was entirely filled with water. The suspension for the turbidity current was prepared in an external mixing tank. Underwater cameras recorded the turbidity current on the slope and the basin floor (Fig. 2B, C). The sediment used consisted predominantly of fine sand with a fraction of silt $\left(D_{10}=25 \mu \mathrm{m}, D_{50}=131 \mu \mathrm{m}, D_{90}=223 \mu \mathrm{m}\right.$; Fig. 3). The substrate in the tank is made of sand with the same grain-size distribution. Any entrainment of substrate therefore would add the same material to the flow as supplied at the inlet. The suspension from the mixing tank was supplied to the set-up with a centrifugal pump. A Krohne Optiflux 2300 was used to monitor the discharge during the experiments. The turbidity current entered the set-up through an inlet box. This box consisted of a $1 \mathrm{~m}$ section with a non-erodible substrate and gradually expanding side walls. An ultrasonic velocity probe (UVP) was used to measure the flow velocity profile in the center of the channel, at equal distance from the inlet during Runs 1, 2, 4, and 5. No velocity measurements were obtained during Run 3. Digital elevation models of the sediment surface were made before and after each run. The difference between these elevation models indicates 
TABLE 2.-Dimensions of the pre-formed channel for the experiments.

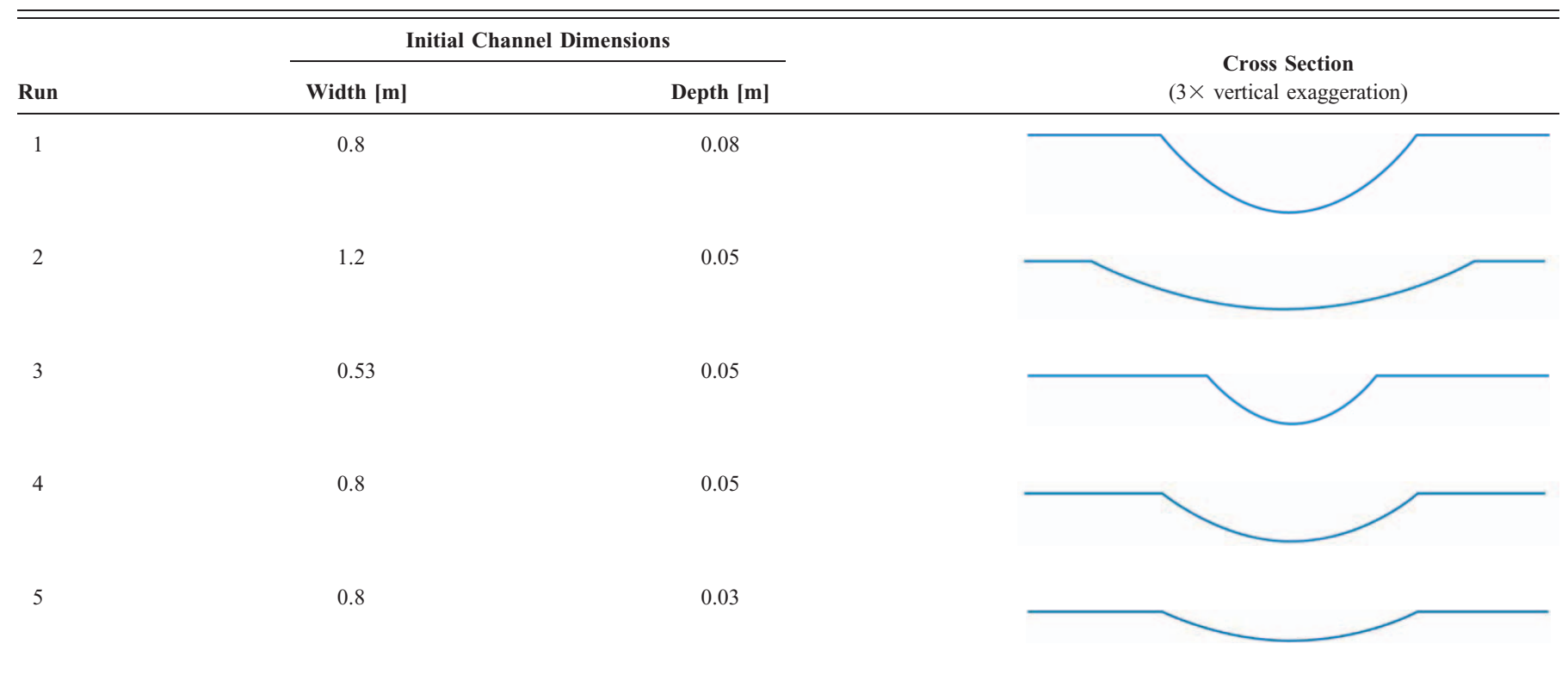

where the flow deposited and eroded sediment. Sediment samples were collected close to the sediment surface. The $\sim 1$-mm-thick silt drape that covered the deposits after each experiment was removed before samples were collected. A laser particle sizer (Malvern Mastersizer) was used to determine the grain-size distribution of each sediment sample.

\section{Mass-Balance Analysis}

We used deposit volume and grain size to reconstruct the downstream change in transported sediment volume and grain size by turbidity currents as they ran out on the slope and basin floor. The initial state of the turbidity current is defined by the suspension in the mixing tank. Volume and grainsize distribution of the suspended sediment at each point in the system were reconstructed by subtracting the sediment that was deposited upstream of that point (Fig. 4). The deposit volumes are derived by subtracting the elevation models before and after the experiments.

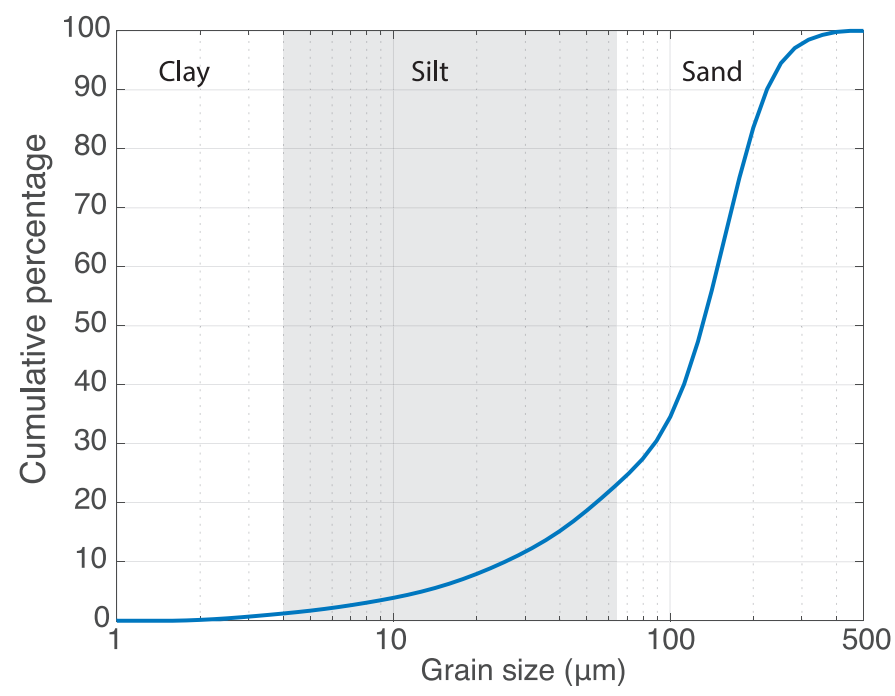

FIG. 3.-Grain-size distribution of the sediment used in the experiments.
Regularly spaced samples of the slope and basin-floor deposits constrained the grain-size distribution of the deposits on the slope and basin floor. The samples were analyzed with a laser particle-size analyzer (Malvern Mastersizer), which provides a grain-size distribution with a bin width of $0.16 \phi$ (using the logarithmic sedimentological phi scale as defined by Krumbein and Aberdeen 1937).

\section{RESULTS}

\section{Deposit Volume Distribution}

We conducted five experiments during which the duration of the turbidity current, sediment grain-size distribution, and discharge were the same. During each of the five experiments, the turbidity current deposited part of its sediment load on the slope section, while the remainder of its sediment formed a lobe on the horizontal basin floor (Fig. 5). During Runs 2, 4, and 5 (Fig. 5B, D, E) deposition on the slope was both inside the channel, as channel fill, and outside of the channel, by the formation of levees. During Runs 1 and 3 (Fig. 5A, C) the turbidity current deposited sediment outside the channel, whereas inside of the channel there was a mix of erosion and deposition.

Initial channel dimensions had a significant effect on the partitioning of sediment volumes between the slope and the basin floor. The fraction of sediment that was transferred to the basin floor was lowest (67\%) during Run 5 (channel width: $0.8 \mathrm{~m}$, depth: $0.03 \mathrm{~m}$; Fig. 6B). The turbidity current in Run 1 flowed through a deeper channel (width: $0.8 \mathrm{~m}$, depth: $0.08 \mathrm{~m}$ ) and delivered $89 \%$ of the sediment to the basin-floor lobe (Fig. 6). The channel in Run 1 can thus be classified as efficient because it delivers the largest fraction of sediment to the basin floor.

Also, the partitioning of sediment volume on the slope between the channel fill and the levees differed between the experiments. The runs with the narrowest channel (Run 3, channel width $0.53 \mathrm{~m}$, depth: $0.08 \mathrm{~m}$ ) experienced the least in-channel deposition relative to levee deposition $\left(\mathrm{V}_{\text {levee }}: \mathrm{V}_{\text {channel }}=85: 15\right)$. The run with the largest channel width (Run 2, channel width $1.2 \mathrm{~m}$, depth: $0.05 \mathrm{~m}$ ) experienced the most deposition in the channel relative to deposition on the levee $\left(\mathrm{V}_{\text {levee }}: \mathrm{V}_{\text {channel }}=34: 66\right)$.

The dimensions of the channel also affected the geometry of the lobe that formed on the basin floor. Figure 7 shows the $25 \mathrm{~mm}$ thickness 


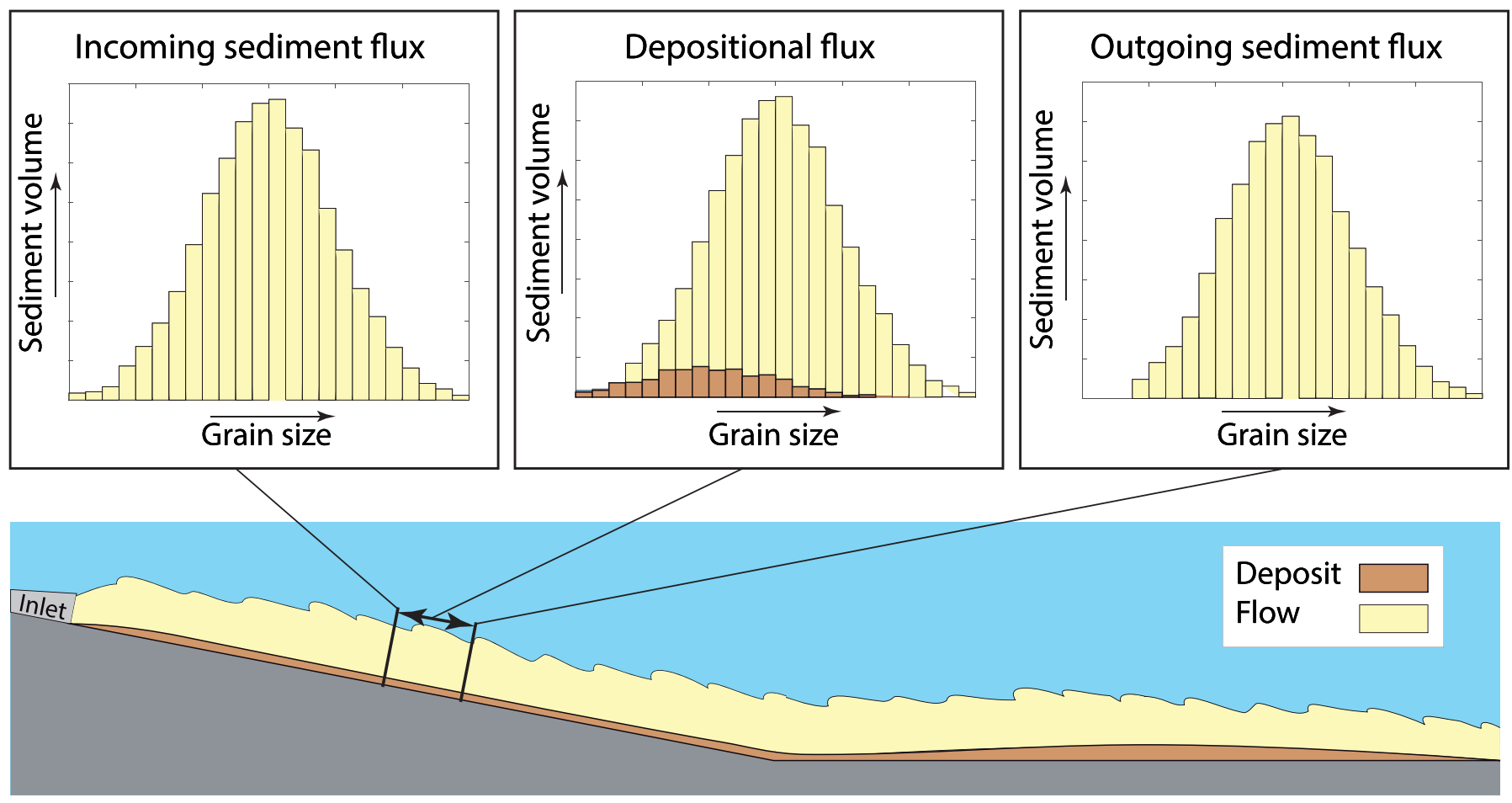

FIG. 4.- Sketch illustrating the reconstruction of downstream mass extraction. The sediment deposited in each section of slope is subtracted from the initial sediment volume in the turbidity current. Deposition typically results in the selective extraction of a certain grain-size fraction. The suspended sediment volume and grain-size distribution thus change downstream.

contours of the lobe formed in each of the experiments. Lobes that are sourced by a channel that is relatively deep (Fig. 7A) or relatively narrow (Fig. 7C) are more elongated, reach farther into the basin, and are also farther detached from the slope. Detached lobes are characterized by a zone of shallow scouring and minor deposition directly downstream of the break of slope. A good example of this erosional type of channel-lobe transition zone in one of the experiments is provided by Profile D in Figure 5C. Similarly, scours near the exit points of submarine channels are also observed in natural systems such as the Niger Delta slope (Prather et al. 2012).

\section{Grain Size of Deposits}

Maps of median grain size of the deposits in each experiment are shown in Figure 8. Each dot indicates the location of a sediment sample, and its color indicates the median grain size. Two patterns are persistent among the runs. Firstly, the lobes are relatively coarse-grained compared to the slope deposits. Secondly, the maximum grain size of the lobes is found in the central part of the lobe.

The median grain size of the slope deposits ranges from 130 to $160 \mu \mathrm{m}$, and the median grain size of the lobe deposits ranges from 150 to $175 \mu \mathrm{m}$. The deposits are thereby consistently coarser than the initial composition of the turbidity current at the inlet $\left(D_{50}=131 \mu \mathrm{m}\right)$. This is primarily a result of bypass of the silt fraction in the flow. This fine sediment fraction remains in suspension, is not incorporated in the deposits, and settles slowly as a thin drape long after the turbidity-current supply at the inlet has stopped.

Grain sizes of levee and channel-fill deposits show a clear relation with channel depth. Representative values for levee and channel-fill grain size are obtained by taking the average of all the deposit samples from these two environments. Figure 9A shows that both the channel fill and the levee deposits become more fine-grained with increasing channel depth. We did not find a clear relationship between the channel width and the grain size of channel-fill or levee deposits (Fig. 9B).

\section{Velocity Structure of Channelized Turbidity Currents}

In Figure 10 we compare time-averaged (interval 10-30 s) velocity profiles of the channelized flow for different runs. Velocity profiles show that the maximum flow velocity was $0.9-1 \mathrm{~m} / \mathrm{s}$ at $1-1.5 \mathrm{~cm}$ above the bed (Fig. 10). The flow velocity at $10 \mathrm{~cm}$ above the bed was $10-20 \%$ of the maximum flow velocity. The exact current thickness depends on the definition of the turbidity-current top, but video footage combined with the velocity profiles suggests that the current thickness is of the order of $0.1 \mathrm{~m}$. The turbidity currents were only partially confined in the channels during the experiments because the thickness of the current thickness exceeded the channel depth $(0.03-0.08 \mathrm{~m})$. Flow velocity at the level that corresponds to the top of the confinement varies between $0.15 \mathrm{~m} / \mathrm{s}$ (Run 1 , channel depth $8 \mathrm{~cm}$ ) and $0.7 \mathrm{~m} / \mathrm{s}$ (Run 5 , channel depth $3 \mathrm{~cm}$ ). The geometry of the channel has a significant impact on the velocity structure of the turbidity current. Figure 10A shows that the current in a shallow channel (Run 5) is flattened compared to a current in a channel of equal width and a larger depth (Run 1). Figure 10B shows that the turbidity current in a wide channel is flatter than the current in a channel of equal depth and a smaller width.

\section{Reconstruction of Turbidity-Current Runout}

Sediment grain-size- and volume-partitioning were reconstructed for three experiments (Runs 1, 4 and 5). The pre-formed channels in Runs 1, 4, and 5 were 8,5 , and $3 \mathrm{~cm}$ deep, respectively, whereas the channel width was $80 \mathrm{~cm}$ in each of these runs. The volume of transported sediment in the turbidity currents decreased downstream as a result of deposition (Fig. 11A). A deeper channel results in less deposition on the slope and a larger 

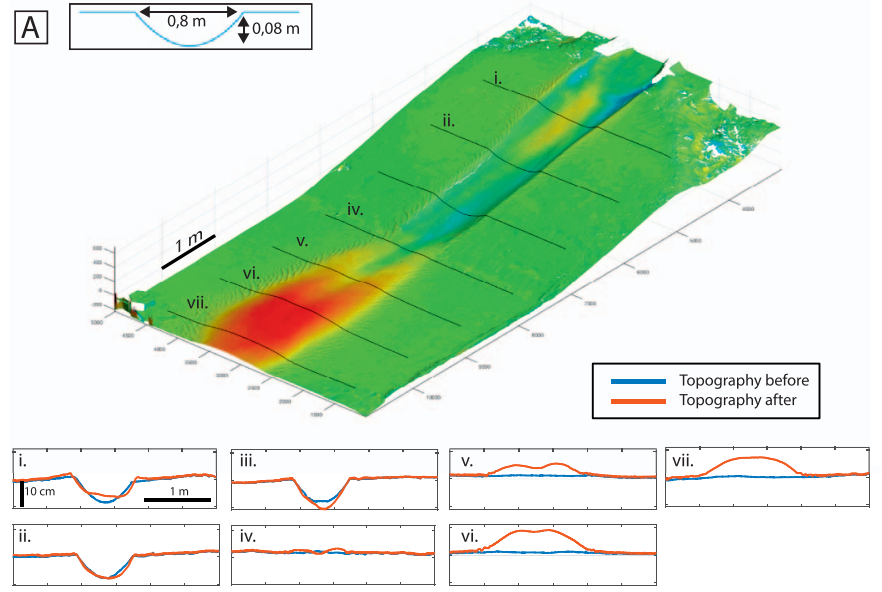

C
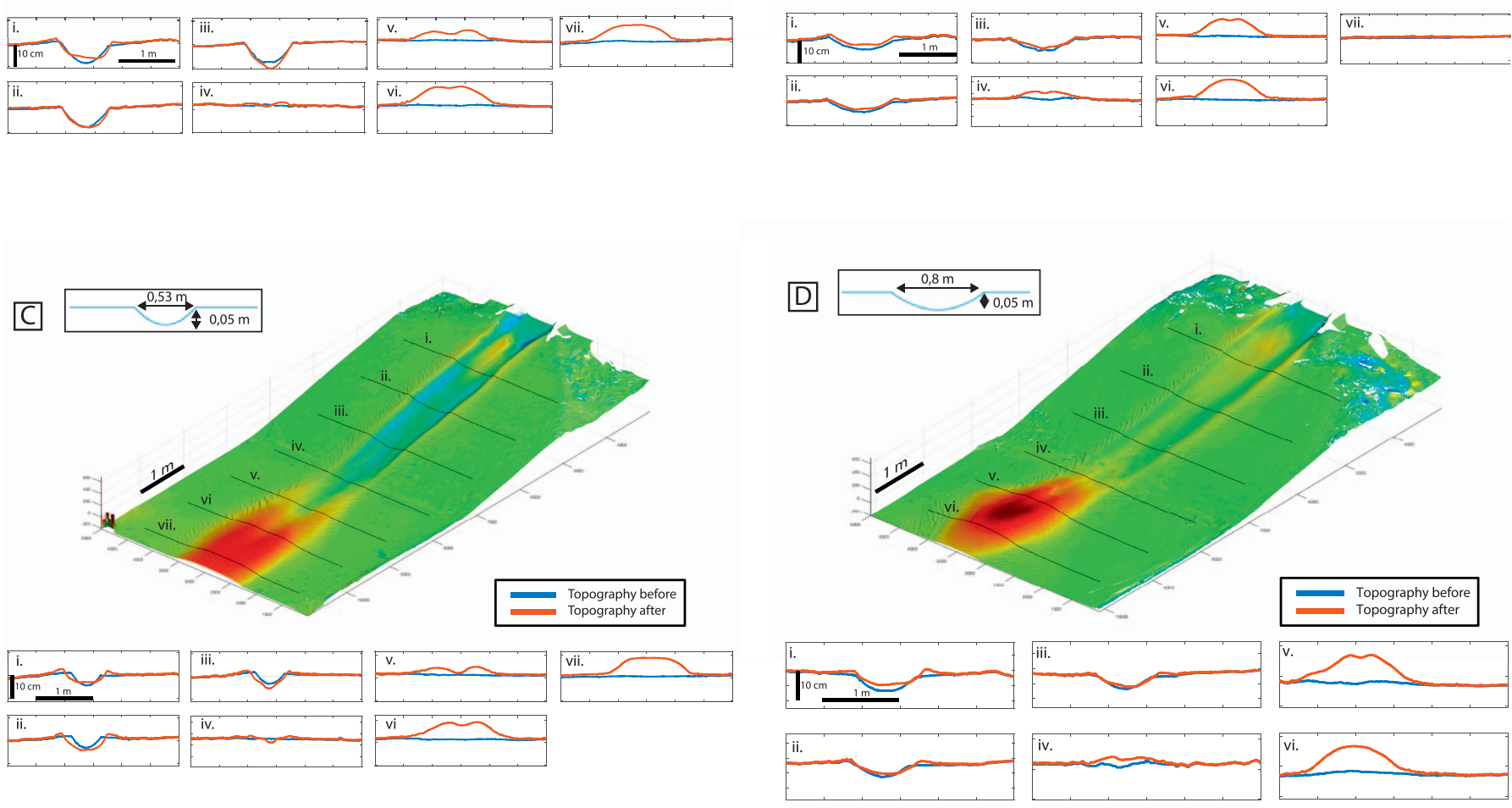

B

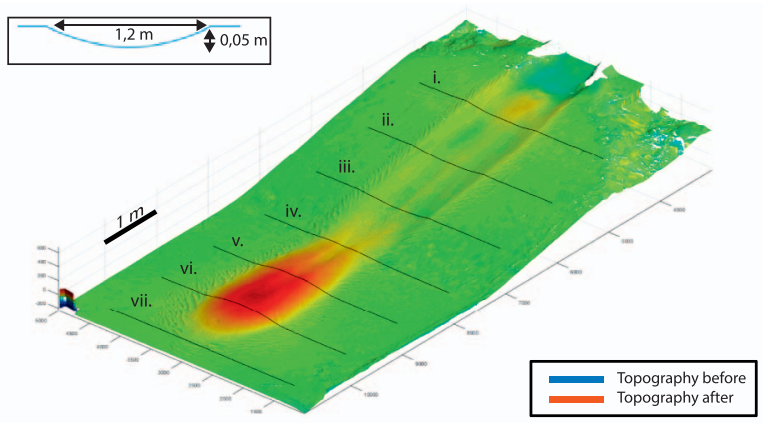

. . . . . . . .

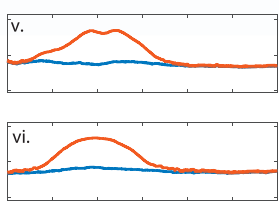

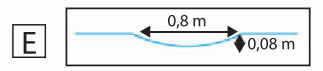

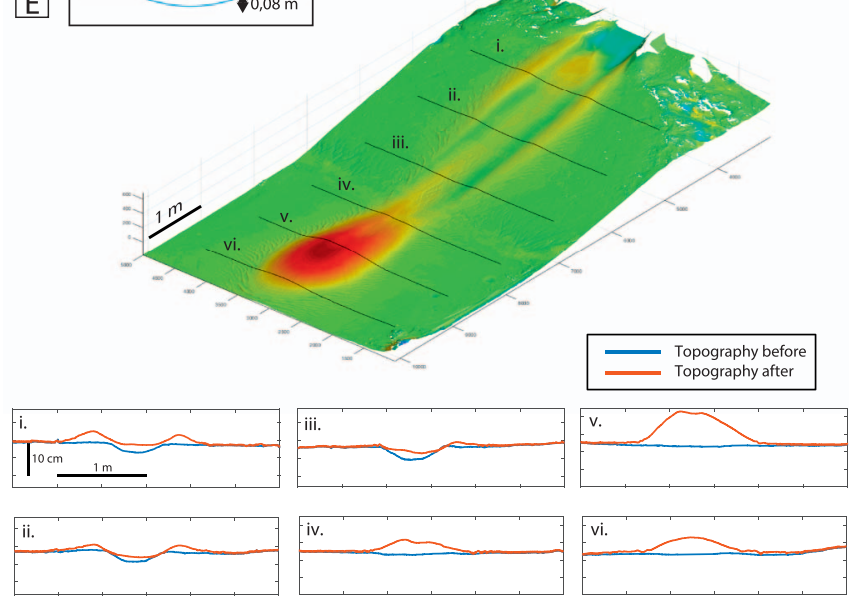

FIG. 5.-Maps of deposition and erosion with cross sections of the channel and lobe at a one-meter interval. A) Results from Run 1, in which the initial channel depth was 8 $\mathrm{cm}$ and the channel width $80 \mathrm{~cm}$. B) Run 2 (channel depth: $5 \mathrm{~cm}$, width: $120 \mathrm{~cm}$ ). C) Run 3 (channel depth: $5 \mathrm{~cm}$, width: $53 \mathrm{~cm}$ ). D) Run 4 (channel depth: $5 \mathrm{~cm}$, width: 80 cm). E) Run 5 (channel depth: $3 \mathrm{~cm}$, width: $80 \mathrm{~cm}$ ). 
A)
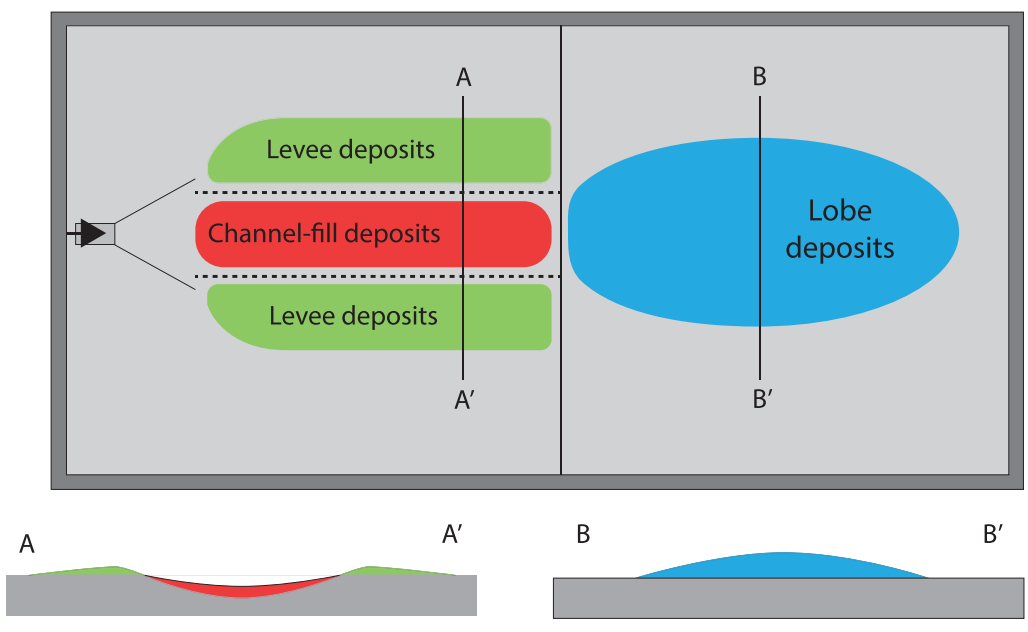

B)

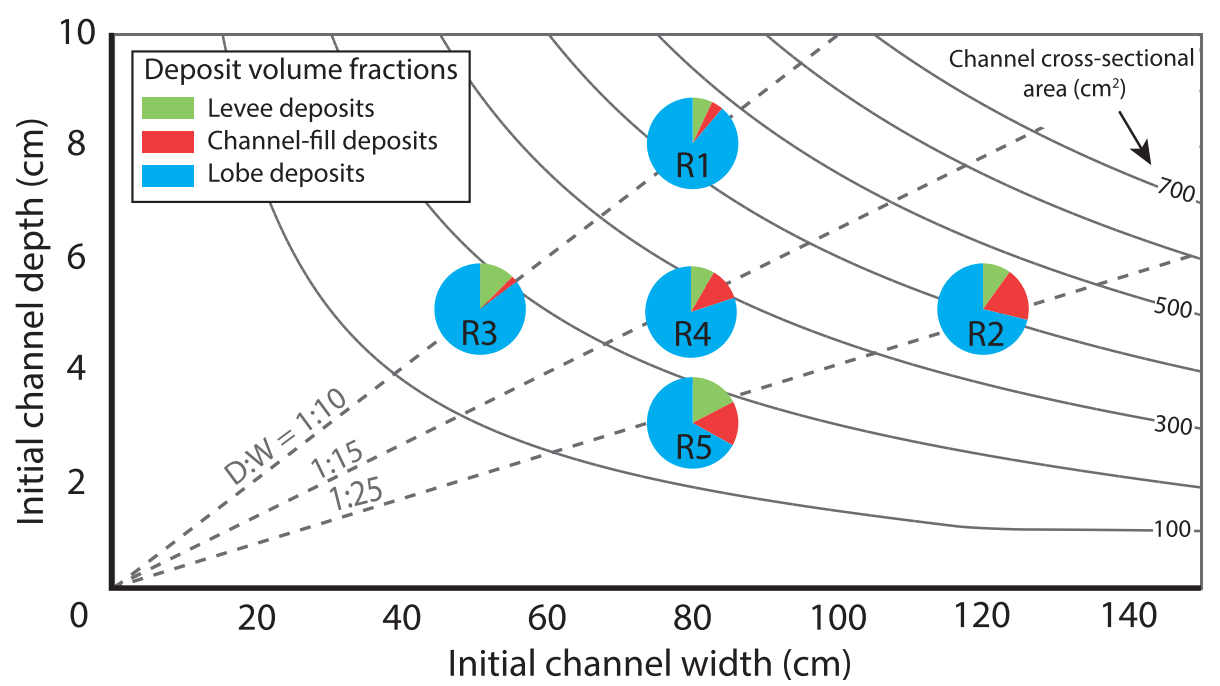

FIG. 6.-A) Sediment bodies distinguished in the experiments. B) Partitioning of sediment volumes between channel, levees, and lobes in experiments with different initial channel dimensions. Each pie chart represents one experiment. Isolines of channel W/D ratio are indicated with dashed lines. Isolines for channel cross-sectional area are indicated with solid lines. proportion of sediment reaching the break of slope. Beyond the break of slope, on the horizontal basin floor, the deposition rate increased. The flow that exited the shallowest channel (Run 5) responded to the change in slope more abruptly and the maximum deposition rate was reached at $\sim 1.5 \mathrm{~m}$ (1.9 times the channel width) downstream of the break of slope. The turbidity current in the deepest channel (Run 1) transported sediment farther out onto the basin floor, and a peak in deposition rate occurred farther out into the basin, at $\sim 2.5 \mathrm{~m}$ (3.1 times the channel width) from the break of slope. Downstream changes of median grain size of the flows and the deposits are shown in Figure 11B. The median grain size of the suspended sediment in the flow shows a small decrease in the slope section and a much sharper decrease along the basin-floor section. The flows that are sourced by deeper channels cover a larger distance on the basin floor before the median grain size of the suspended sediment is significantly affected by extraction of the coarse-grained sediment due to deposition on the lobe.

Detailed grain-size distribution of the flow and the deposits of Run 5 are compared at various positions in the system (Fig. 12A). Silt-size sediment becomes more abundant in the flow farther downstream in the system as the sand-size sediment fraction is lost due to deposition. The downstream change in sediment volume per grain-size class is shown in Figure 12C. This figure illustrates that sediment finer than $\sim 100 \mu \mathrm{m}$ completely bypasses the lobe. During the experiments, it was observed that the dilute suspension cloud with fine-grained sediment reflected against the back of the flume tank and slowly settled in the minutes after the run to form a drape that is $\sim 1 \mathrm{~mm}$ thick. This silt fraction would have been deposited farther downstream in a natural system.

\section{DISCUSSION}

\section{Channel Geometry and Sediment Partitioning}

The volume and grain size of sediment that reaches the downstream end of a channel section depend on the initial sediment load of the turbidity current and the fraction that is extracted on the slope. The initial sediment caliber delivered to the canyon head determines the range of grain sizes and the volume of sediment that are deposited in down-dip locations. Part of this sediment load is deposited on the lower slope, especially where aggradational channels and levees are present. These channel-associated deposits are generally finer than the input sediment, mostly because the overbank deposits are formed from the dilute, finer-grained tops of turbidity currents. This preferential deposition of finer sediment causes the flow composition to become coarser down-flow (Fig. 13). The coarser sand fraction is subsequently concentrated in the lobe.

The experiments show that sediment is partitioned into channel fill and levees on the slope in variable volume fractions depending on the channel geometry. These results are in line with previous experiments that showed 

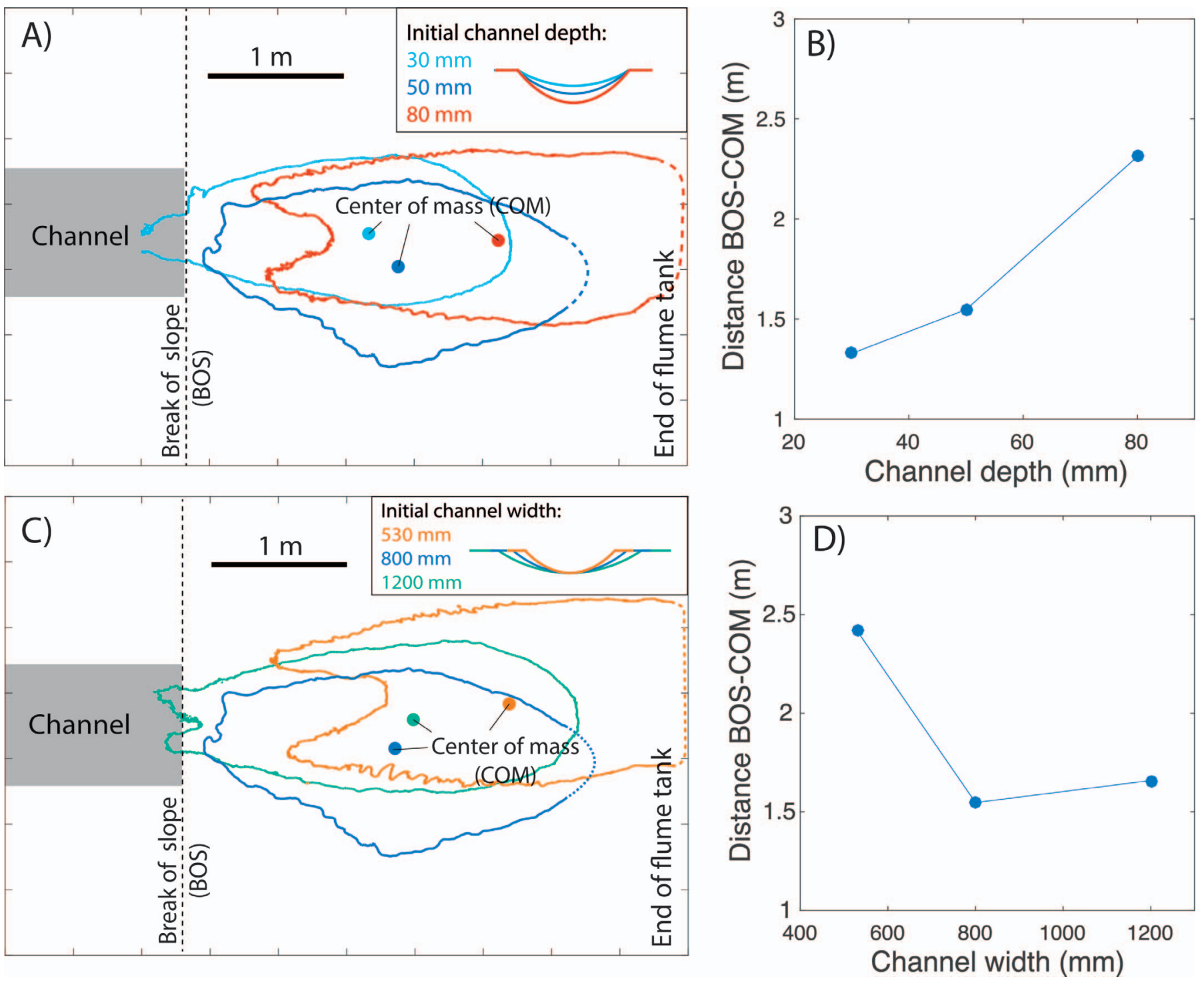

FIG. 7. - Effect of channel dimensions on the geometry of the lobe formed on the basin floor. The $25 \mathrm{~mm}$ thickness contour of each lobe is shown. A) Lobe geometry as a function of channel depth. A shallow channel results in a broad lobe that onlaps onto the slope. Deeper channels result in slope-detached sedimentation of more elongate lobes. B) The center of mass of the lobe is located farther into the basin when the channel is deeper. C) Lobe geometry as a function of channel width. Wider channels result in wider lobes with depocenters close to the break of slope (BOS). Narrow channels result in slope-detached sedimentation and more elongate lobe deposits with depocenters farther into the basin. D) The center of mass of the lobes shifts basinwards with increasing channel depth.

that channel efficiency (i.e., the fraction of sediment that bypasses the channel section) increases with channel depth (Kane et al. 2008; de Leeuw et al. 2016). The mechanisms through which channel dimensions affect sediment partitioning in deep-water systems are assessed in detail below.

\section{Volume Partitioning}

We assessed the correlation of levee volume and channel fill with four channel geometrical parameters: depth, width, W/D ratio, and crosssectional area. Levee volume has a high correlation with channel depth $\left(\mathrm{R}^{2}\right.$ $=0.62)$ and with channel cross-sectional area $\left(\mathrm{R}^{2}=0.58\right)$ (see Appendix; Fig. 9A). The correlation between levee volume and channel depth is intuitive because shallower channels have more overspill (Straub and Mohrig 2008). Velocity data confirm that the supra-channel portion of the current is larger for shallower channels (Fig. 10A), which explains the high sediment flux to the overbank area. Additionally, at equal channel depth, a narrower channel is associated with a larger levee volume (Fig. 9B). Narrow channels have a smaller cross-sectional area and will therefore accommodate a smaller part of a turbidity current inside the channel. The difference in current thickness between a current in narrow and wide channels with equal depth is evident from the velocity data (Fig. 10B). However, levee volume for the run with the widest channel (Run 2) is larger than the levee volume for the intermediate-width channel (Fig. 9B). This may be due to the large volume of channel-floor deposition in the wide channel, which results in an effective decrease in channel depth, which promotes overspill from the channel.

Channel-fill deposit volume has a high correlation $\left(R^{2}=0.84\right)$ with channel W/D ratio (see Appendix). where a low W/D ratio leads to less deposition. Channels with a low W/D ratio have steep banks, and lateral spreading of the flow is therefore prevented. This results in a larger flow thickness and consequently a higher shear velocity. This allows the 

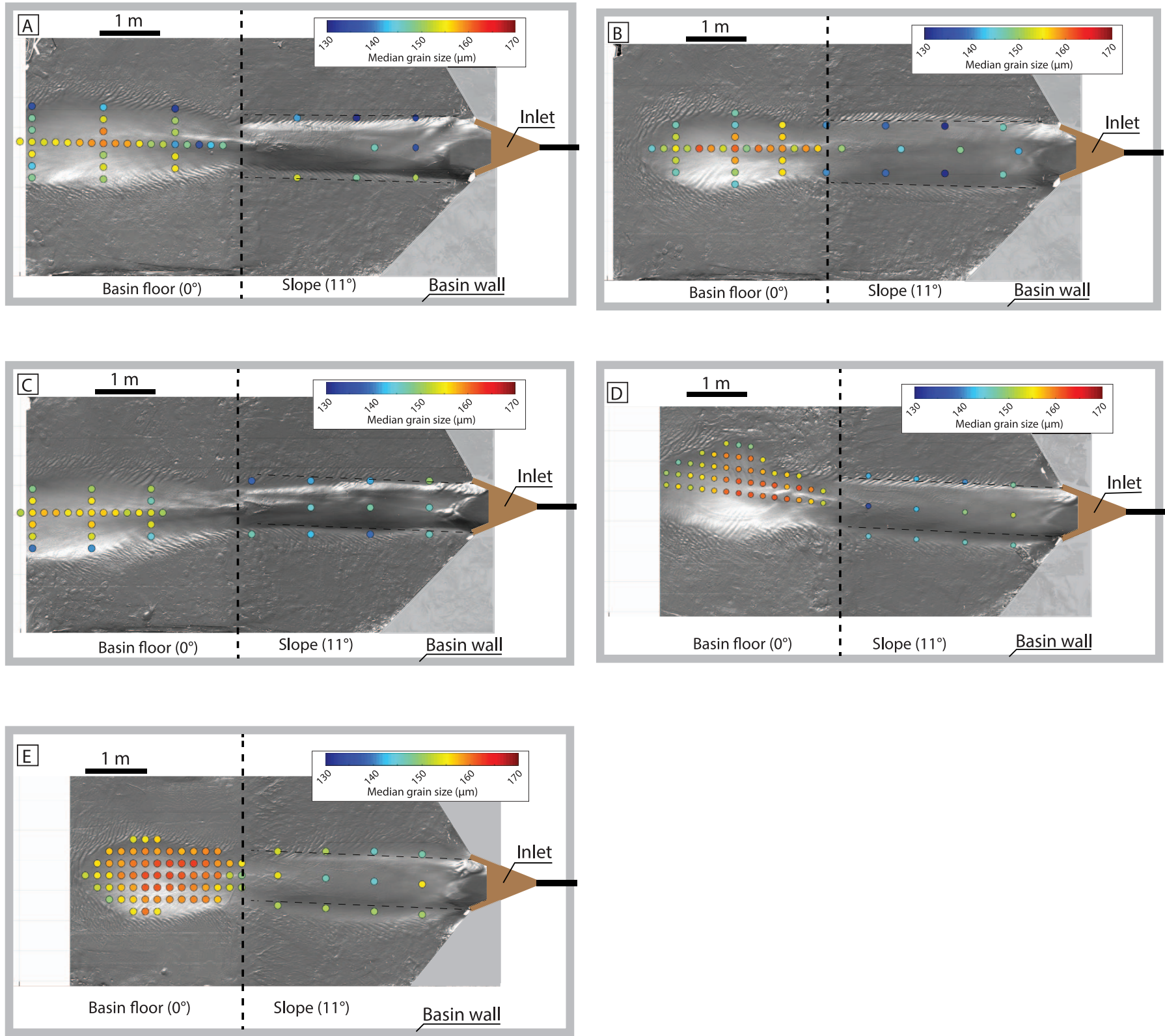

FIG. 8. - Maps with median grain size of deposit samples collected after each experiment. A) Results from Run 1 in which the initial channel depth was $8 \mathrm{~cm}$ and the channel width $80 \mathrm{~cm}$. B) Run 2 (channel depth: $5 \mathrm{~cm}$, width: $120 \mathrm{~cm}$ ). C) Run 3 (channel depth: $5 \mathrm{~cm}$, width: $53 \mathrm{~cm}$ ). D) Run 4 (channel depth: $5 \mathrm{~cm}$, width: $80 \mathrm{~cm}$ ). E) Run 5 (channel depth: $3 \mathrm{~cm}$, width: $80 \mathrm{~cm}$ ).

currents to keep more sediment in suspension and therefore limits deposition on the channel floor.

In combination, levee and channel-fill deposit volumes determine the efficiency of sediment delivery to the basin floor. Levee and channel-fill deposition respond differently to changes in channel geometry. A low channel W/D ratio minimizes channel-fill deposition, while a large channel depth minimizes deposition on the levees. Thus, the efficiency of sediment delivery to the basin floor is greatest when a low channel W/D ratio occurs in combination with a channel depth that limits overspill.

Finally, the channel geometry sets the velocity structure of the flow that enters the basin flow. The experiments illustrate that a high-efficiency channel (i.e., deep and low W/D ratio) results in a flow with a higher velocity and larger thickness (Fig. 10). The thicker and faster flow reaches farther into the basin. The resulting lobe is therefore more elongated, and its center of mass is located far from the break of slope (Fig. 7).

\section{Grain-Size Partitioning}

Generally, in our experiments, the levee and channel-fill deposits are finer grained than the deposits of the basin-floor lobe (Fig. 8). We identify two main factors that control the grain-size distribution of sediment deposited from turbidity currents: (1) the vertical sorting of sediment in the flow and (2) the grain-size spectrum available in the flow.

Vertical sediment segregation in the flow controls grain-size distribution of the sediment that is deposited at the base of the flow and the sediment in the overspilling part of the current that escapes from the channel (Fig. 13). An upward decrease in grain size in turbidity currents has been measured 

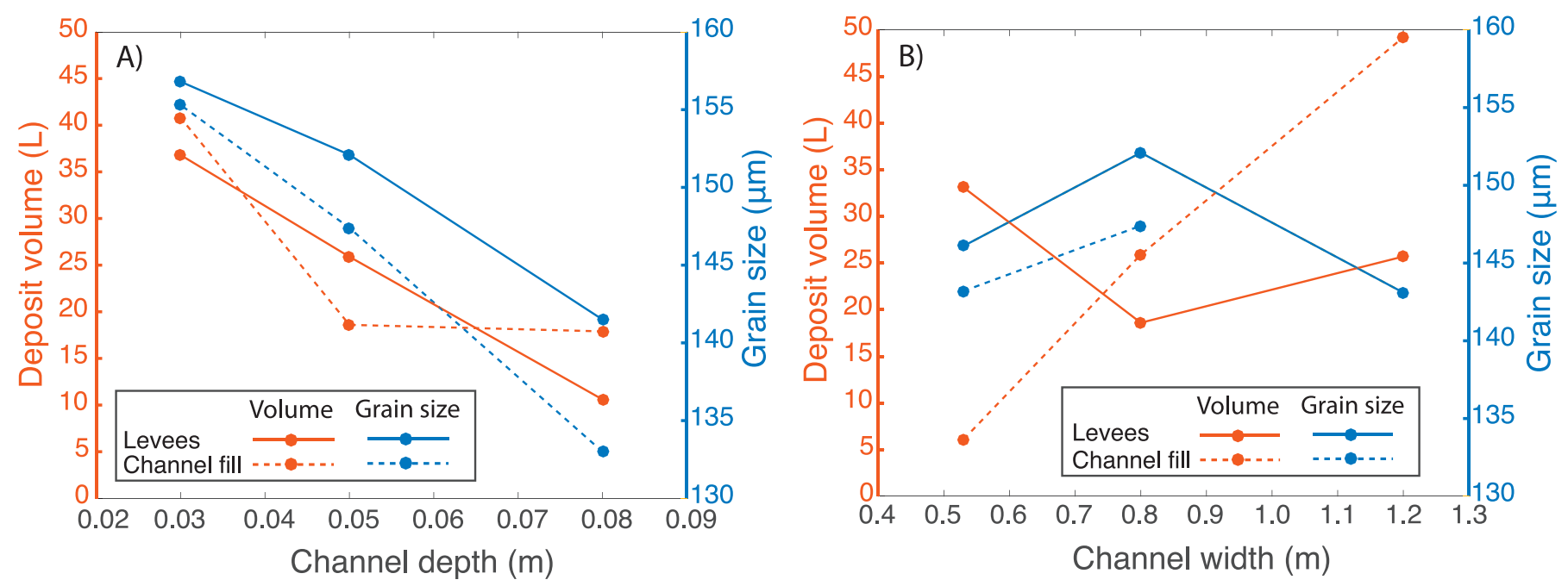

FIG. 9.-Effect of channel dimensions on grain-size- and volume-partitioning between levees and channel fill. A) Effects of channel depth. An increase in channel depth results in a decrease in the volume and grain size of sediment deposited as levees and channel fill. B) Effects of channel width. An increase in channel width results in an increase in channel-fill volume. Levee volume and deposit grain size do not show a clear relation with channel width.

directly in small experimental turbidity currents (e.g., Garcia 1994; Baas et al. 2005) and has been reconstructed from submarine channel deposits (e.g., Jobe et al. 2017; Symons et al. 2017). Previous experiments (de Leeuw et al 2018) with boundary conditions similar to those of the experiments presented here show that an upward decrease in suspended sediment grain size is also recorded in the levees. Similarly, in the present experiments, the levee grain size decreases as channel depth increases (Fig. 9A). We interpret this to be the result of grain-size stratification. Deposits derived from the base of turbidity currents (channel fill and lobe) are expected to be coarser grained than the levee deposits. Lobe deposits indeed have a larger median grain size than levees in each of the experiments. However, channel-floor deposits formed in the experiments are finer grained than the levees (Fig. 9A). This pattern is dissimilar from natural systems, where channel-fill deposits are usually coarser grained than the genetically related overbank deposits (Hansen et al. 2015). The small grain size of the channel fills in the experiments may indicate that it was at least partially deposited during the waning phase of flow, near the end of the experiments when the sediment that was still in transport was relatively fine-grained.

\section{Channel Evolution and Sediment Partitioning}

Progressive changes in channel confinement occur in most submarine channels (Maier et al. 2013; Ortiz-Karpf et al. 2015; Pemberton et al.
2016), and this has important implications for the stratigraphic evolution of deep-water systems (Hodgson et al. 2016). Each of the experiments can be considered to represent a different phase in the evolution of a channel. During the incipient phases of channel formation, the confinement width and depth are likely small compared to the flow size. As a result, there is a large sediment flux with a broad range of grain sizes that flows onto the levees. This situation is represented by Run 5 . The flow that reaches the downstream end of the channel will therefore be significantly altered relative to the input composition (Fig. 14A). Flow capture by a low-relief channel or slope gully can focus turbidity-current flow and promote erosion in the thalweg as well as buildup of the levees (de Leeuw et al. 2016). As the degree of confinement increases due to levee build-up, the volume and grain size of sediment deposited on the levees decreases (Fig. 14B). This situation is represented by Run 1. During the later stages of channel evolution, a channel typically shallows and widens due to extensive deposition on the channel floor (e.g., Hubbard et al. 2014) (Fig. 14C). It should be noted that we still have limited understanding of the allogenic and autogenic processes that drive the full cycle of submarinechannel cutting and filling (Hodgson et al. 2016). Deposition on the channel floor extracts relatively coarse sediment from the flow. In addition, the deposition on the channel floor reduces channel relief, and this increases overspill. The remaining flow at the downstream end of the
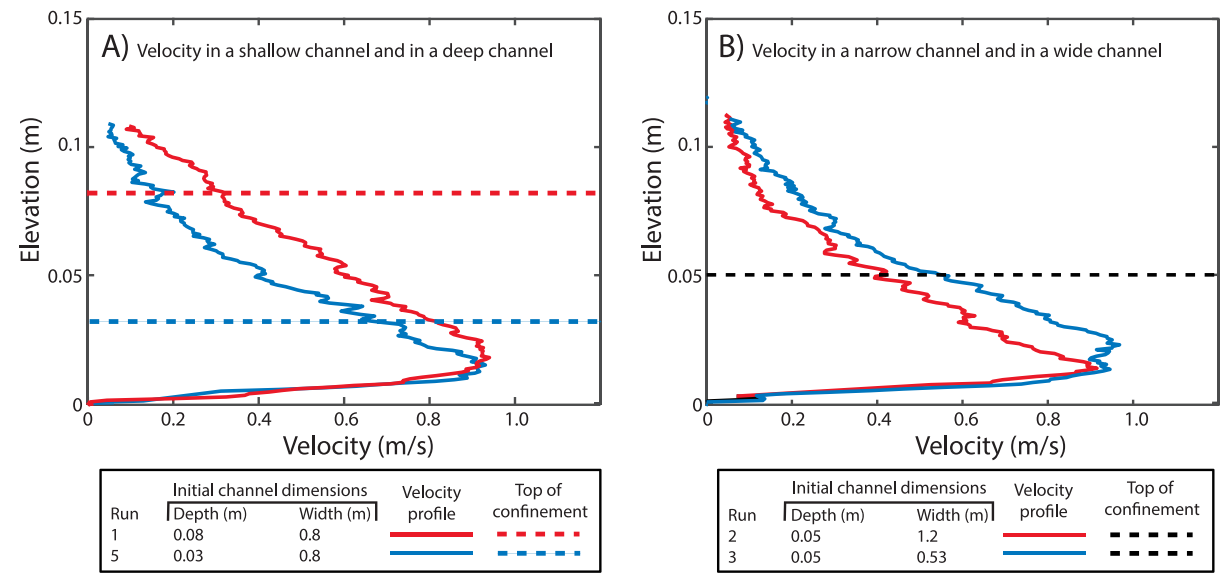

FIG. 10.-Velocity profiles of turbidity currents measured in the center of each channel. A) A turbidity current in a deep channel has a larger thickness than a turbidity current in a shallow channel. B) A turbidity current in a narrow channel has a larger thickness and velocity maximum than a turbidity current in a wide channel. 

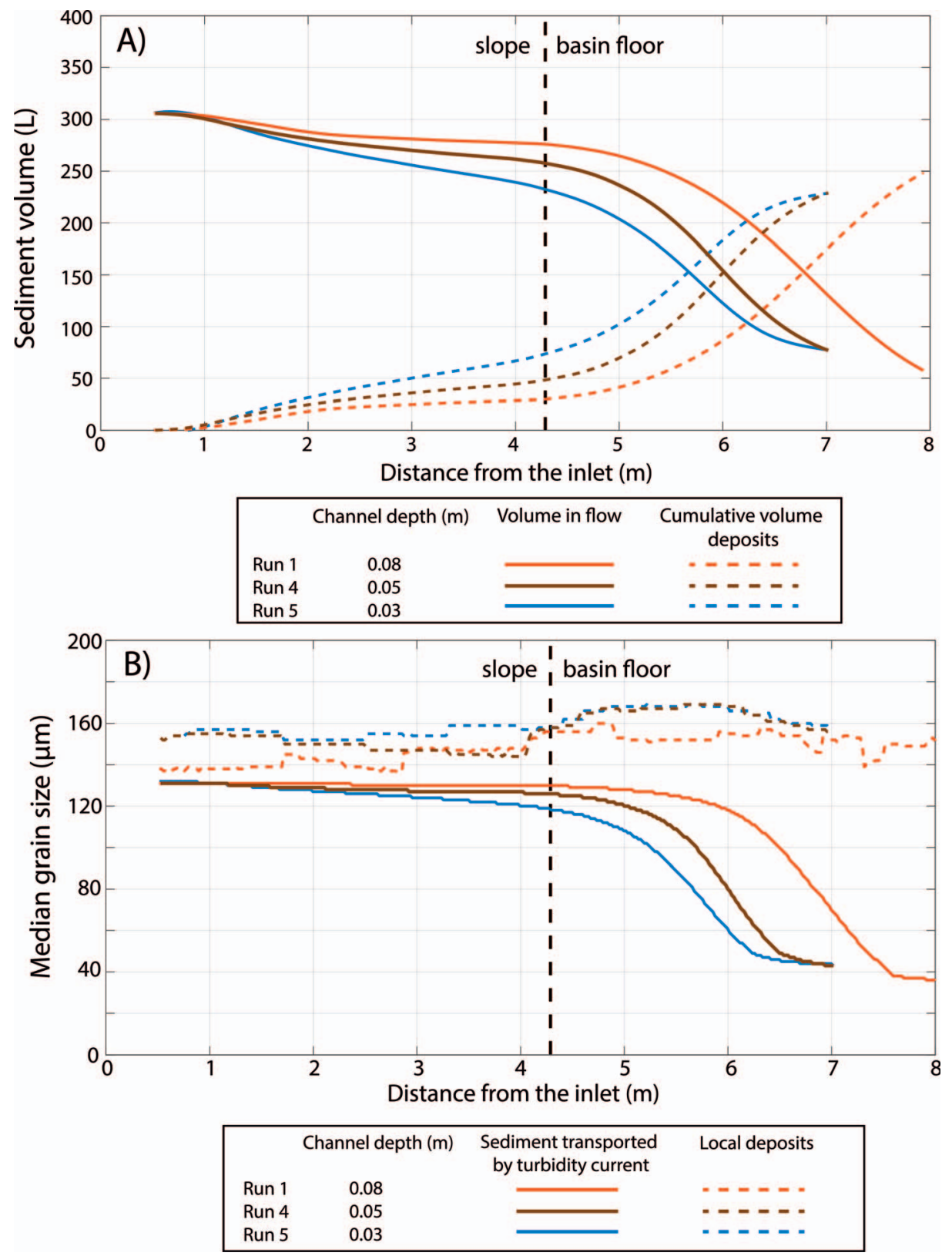

Fig. 11.-Downstream changes in flow size and composition. Results are shown for Run 1 (channel depth $=8 \mathrm{~cm}$, width $=80 \mathrm{~cm}$ ), Run 4 (channel depth $=5 \mathrm{~cm}$, width $=80 \mathrm{~cm}$ ), and Run 5 (channel depth $=3 \mathrm{~cm}$, width $=80 \mathrm{~cm}$ ). A) Downstream change in transported and deposited sediment volume. B) Downstream change in transported and deposited sediment grain size. channel section is significantly reduced in volume, and the grain-size distribution is changed according to the components that are extracted. This phase of channel evolution may be represented by Run 2 .

This analysis emphasizes the existence of an optimal bypass phase of the channel, when the maximum volume of supplied sediment is transferred through the slope system. The efficient transfer of sediment in mature channels implies that the grain-size distribution at the upstream supply will be similar to that of the sediment that reaches the basin floor. The situation is different during the early phase of channel evolution, when a large overbank flux from a shallow, immature channel causes the effective extraction of the fine-grained sediment fraction. This leads to the stratigraphic prediction that initial sediment pulses onto the basin floor are expected to be coarse-grained relative to the sediment composition that is delivered to the basin in later efficient-bypass stages of the channel system. It is important to note that the trends discussed here are generated within the slope system, and are thus autogenic, without the need for external forcing or allogenic mechanisms.

\section{Sediment Partitioning in Natural Systems Compared with Experiments}

Volume Partitioning.-Estimates of sediment volumes in different components of deep-water systems (levees, channel fills, lobes, slope deposits, basin floor deposits) are becoming increasingly available through outcrop and subsurface studies. Some datasets with volume estimates cover both the channel and lobe segments of deep-water systems (Fig. 15B, C)(Jegou et al. 2008; Carvajal and Steel 2012; Paola and Martin 2012; Van der Merwe et al. 2014; Picot et al. 2016), while other datasets cover the channel-levee system and the partitioning between channel fills and levees therein (Fig. 15E, F; Straub et al. 2012; Sylvester et al. 2012).

Partitioning between channel-related deposits (levees and channel fills) and lobes was documented for the Congo Fan (Picot et al. 2016) and the Amazon Fan (Pirmez and Imran 2003; Jegou et al. 2008). Several other studies (Carvajal and Steel 2012; Van der Merwe et al. 2014; Prather et al. 2017) documented partitioning of sediment volumes between the submarine slope and basin floor. Submarine slope stratigraphy is typically 


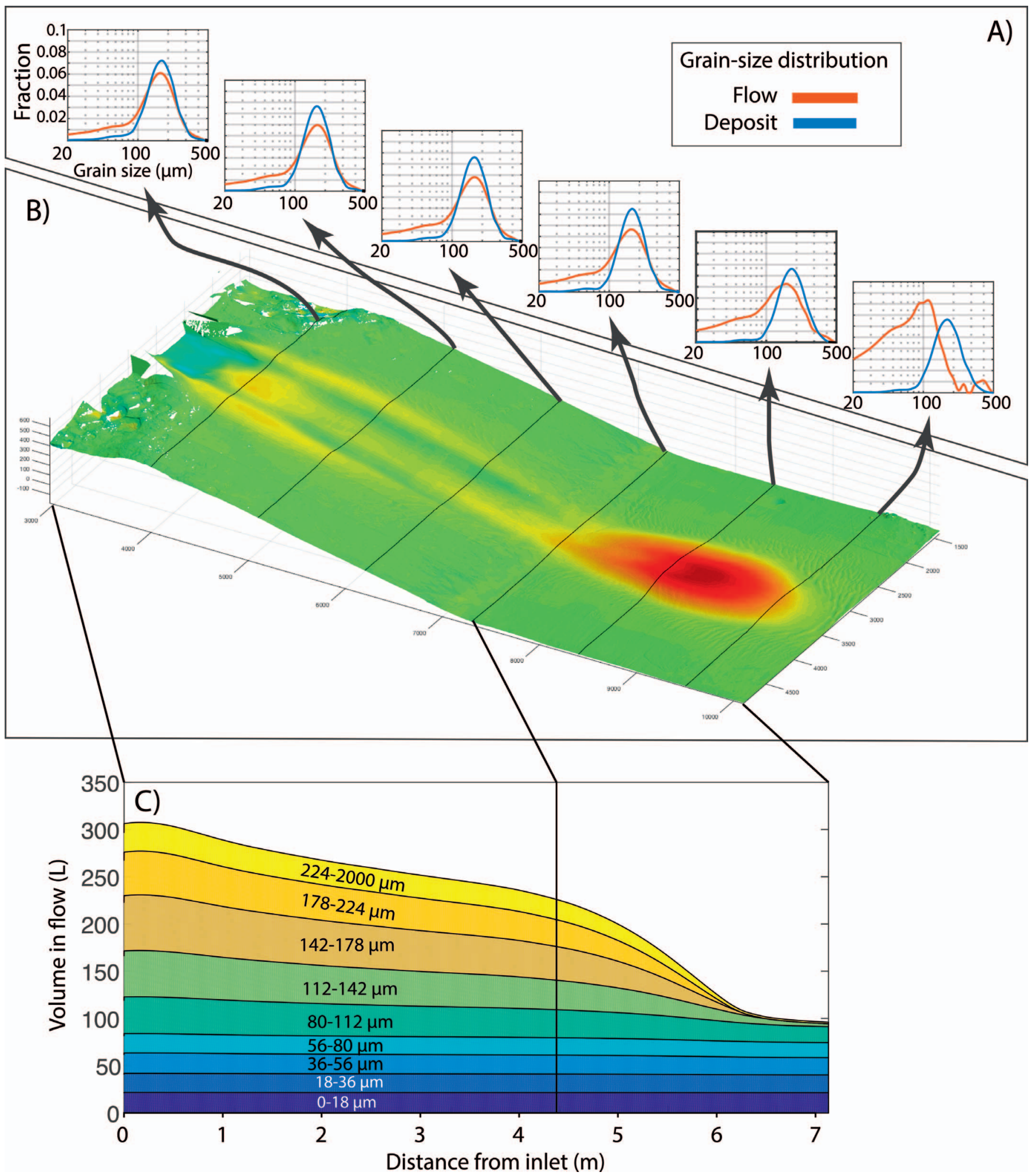

FIG. 12.-Representations of the downstream extraction of mass in Run 5 (channel depth $=3 \mathrm{~cm}$, width $=80 \mathrm{~cm}$ ). A) The grain-size distribution of the sediment in the flow and the deposits are shown at multiple positions in the system. B) Map of deposition and erosion. The same color scale as in Figure 5 is used. C) Volume of sediment transported in the flow for various sediment grain-size classes. Note that sediment coarser than $\sim 100 \mu \mathrm{m}$ is extracted from the flow while sediment finer than $\sim 100 \mu \mathrm{m}$ is completely bypassed to the downstream end of the system. 


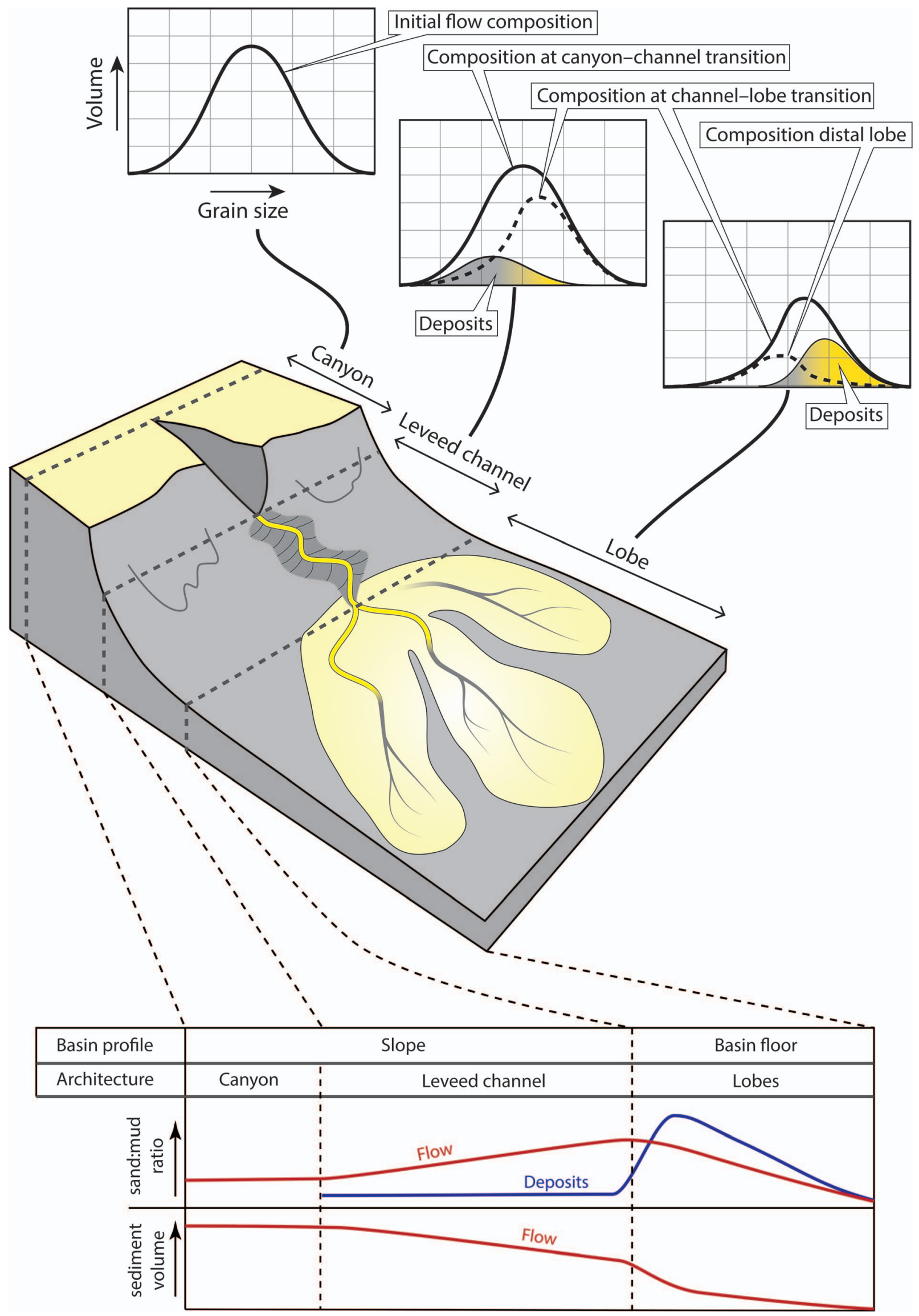



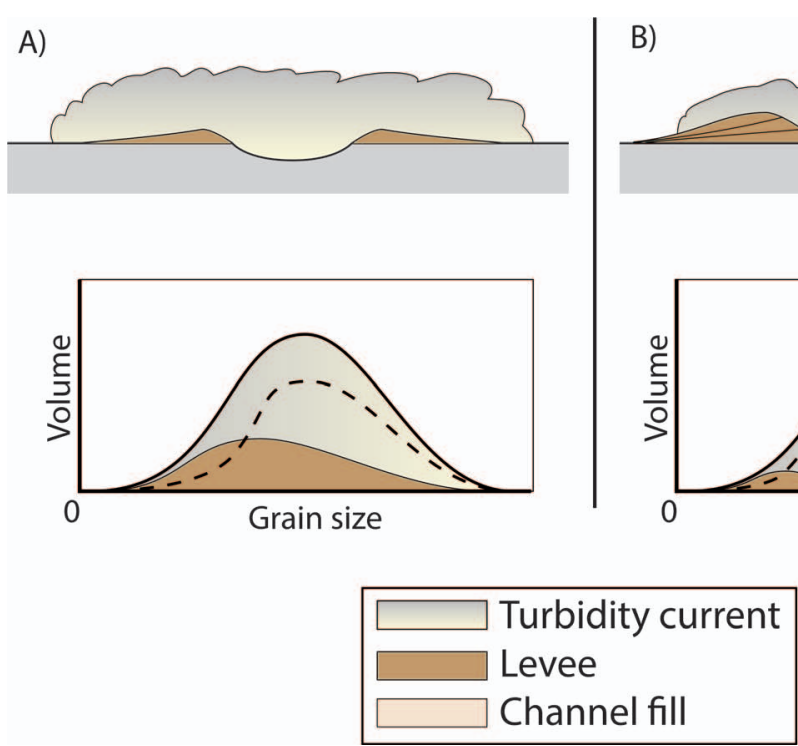
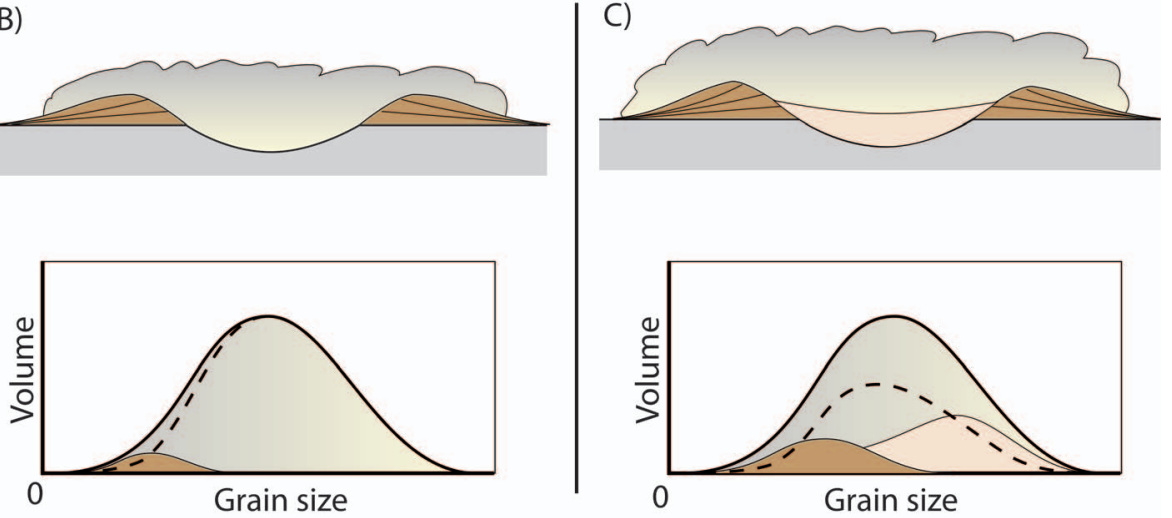

FIG. 14.- Schematic illustration of the effect of channel evolution on sediment partitioning. A) An immature channel has little relief. The turbidity current is relatively inefficient because a large volume of sediment is lost to overspill from the channel. The overspilling current has a broad grain-size distribution. B) A mature channel has a greater depth due to further growth of the levees and incision in the channel thalweg. The turbidity current is efficient because only a small fraction of sediment is lost due to overspill. The overspill is very fine-grained. C) During the late stages of channel evolution the channel gets filled with sediment. The turbidity current deposits sediment both on the channel floor and on the levees. Deposition on the levees preferentially extracts fine sediment from the flow while deposition on the channel floor preferentially extracts coarse sediment from the flow.

dominated by channel-related deposits (Posamentier and Kolla 2003), but the two are not necessarily equivalent because the channel-lobe transition can migrate upstream or downstream. Similarly, lobes are common on the basin floor, but channel fills may also be present in this domain.

The volume of slope deposits relative to basin floor deposits and the volume of channel-related deposits relative to lobes vary greatly between deep-water systems (Fig. 15B). The lobes associated with the Amazon Fan constitute only a minor volume compared to the channel-related deposits, while in the Fort Brown Formation the channel-related deposits and lobes are comparable in volume. In general, it seems that for large, mud-rich fan systems on continental margins, such as the Amazon Fan and the Congo Fan, lobes form a comparatively small fraction of the total fan volume. For systems such as the Washakie and Karoo Basin, the lobes or basin-floor deposits form a larger volume fraction. These systems were located in intracontinental basins and had a higher portion of sand and a shorter slope length than the Amazon Fan. Thus, the characteristic transition in deepwater systems from channels to lobes is not only tied to a certain degree of mass extraction. Paola and Martin (2012) hypothesized that, to first order, in any sediment routing system similar deposit characteristics are likely to occur at similar degrees of mass extraction from the source into a basin. Basin configuration is a key control on sediment composition supplied to deep-water systems (Covault et al. 2012), and the deep-water systems that are compared in this study are vastly different in terms of basin configuration and caliber of sediment supplied. The comparatively small lobes in the more mud-prone systems, such as the Amazon Fan, might be explainable as follows: a condition of self-channelization can be maintained as long as sufficient mud and silt are available in the flow to build up levees (Posamentier and Kolla 2003). A loss of confinement due to depletion of sediment of silt size and finer will therefore occur only at a high degree of mass extraction in mud-rich systems. Systems with a more sand-prone sediment supply will be depleted in mud at a lower degree of mass extraction and have lobes that form a larger volume fraction of the sediment load. Such an interpretation implies that there may be a critical sand:mud ratio at which a channel transition will occur. Thus, basin configuration and the related sediment caliber (Covault et al. 2012) emerges as an important control of the "anomaly with respect to the reference model" (Paola and Martin 2012) when it comes to relating lobe volume and composition to mass extracted along the routing system.

In the experimental systems (Fig. 15C), a much larger fraction of sediment is partitioned into the lobe (67-89\%) than in any of the natural systems considered here (3-50\%) (Fig. 15B). This is largely the result of the geometry of the set-up, where a short section of slope (slope length is 3.6-8.1 times the channel width) is followed by a horizontal basin floor where the flow deposits sediment at a high rate to form a lobe. Such a profile with a sharp break occurs on some active margins where the slope is affected by faults, but more commonly slope profiles are graded (Kneller 2003). A larger fraction of sediment would probably be partitioned into the channel fill and levees in the experiments if the slope section were longer.

Partitioning of sediment volumes between channel fills and levees has been documented for a channel network on the upper continental slope offshore Brunei (Fig. 1B) (Straub et al. 2012) and for the Fuji-Einstein system in the upper to mid-slope of the Gulf of Mexico (Sylvester et al. 2012). Levee volumes are significantly larger than channel-fill volumes in these systems (Fig. 15E). The experiments reported here show highly variable sediment volume partitioning between levees and channel fill (Fig. $15 \mathrm{~F})$. Channel-fill volumes relative to levee volumes are small in some experiments (Runs 1, 3, 5) while channel fill volumes exceed the levee volume in others (Runs 2, 4). Runs 1 and 3 have the largest levee volume relative to channel-fill volume (Fig. 15F), while the volume of channelrelated deposits (levees and channel fills combined) was low for these runs,

FIG. 13.- Summary figure illustrating the partitioning of sediment in a deep-water system consisting of a canyon section, a leveed channel, and a lobe. Lower panel shows the downstream evolution of flow composition (sand:mud ratio) and size as a result of downstream mass extraction due to deposition (figure inspired by Posamentier and Kolla (2003) and sepmstrata.org). 

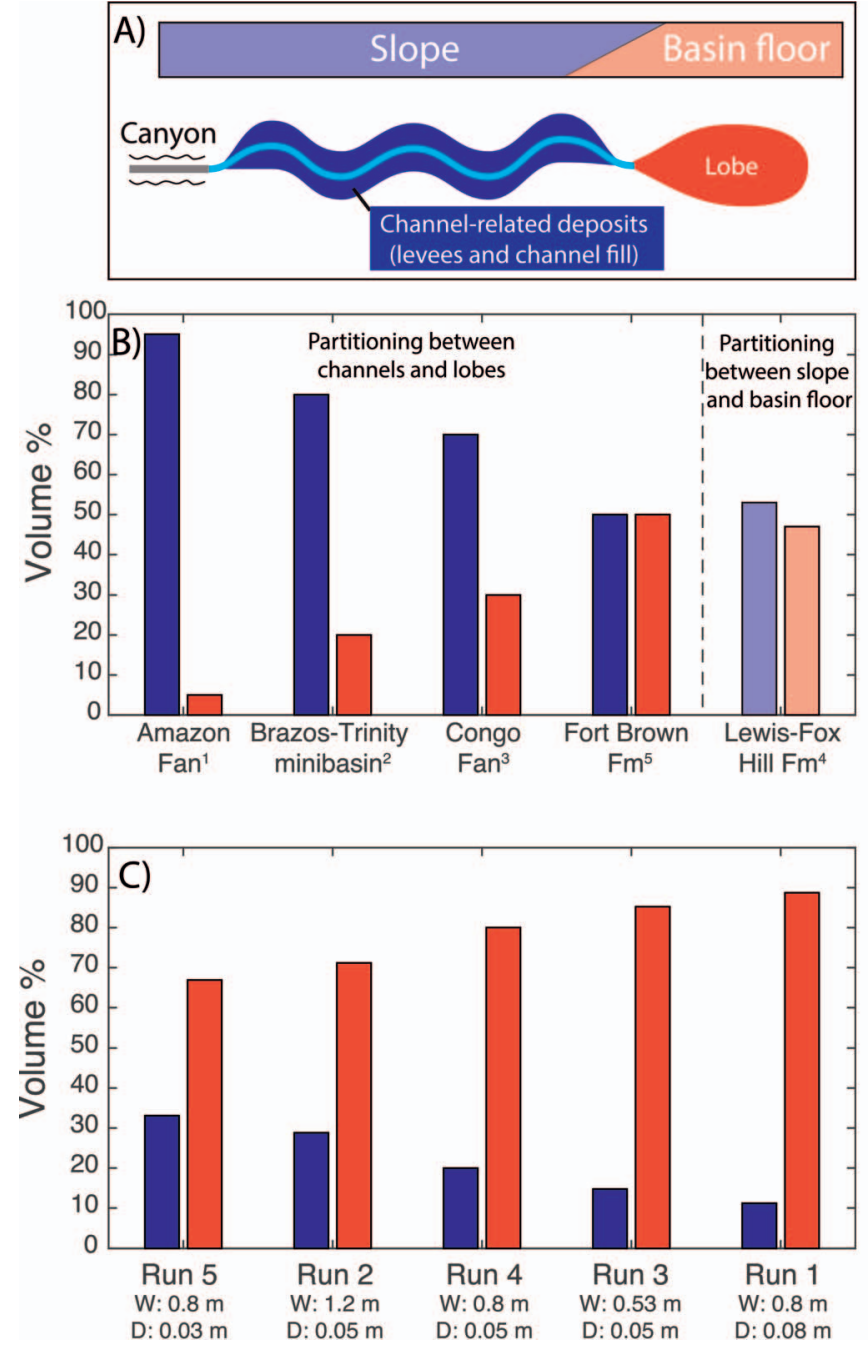
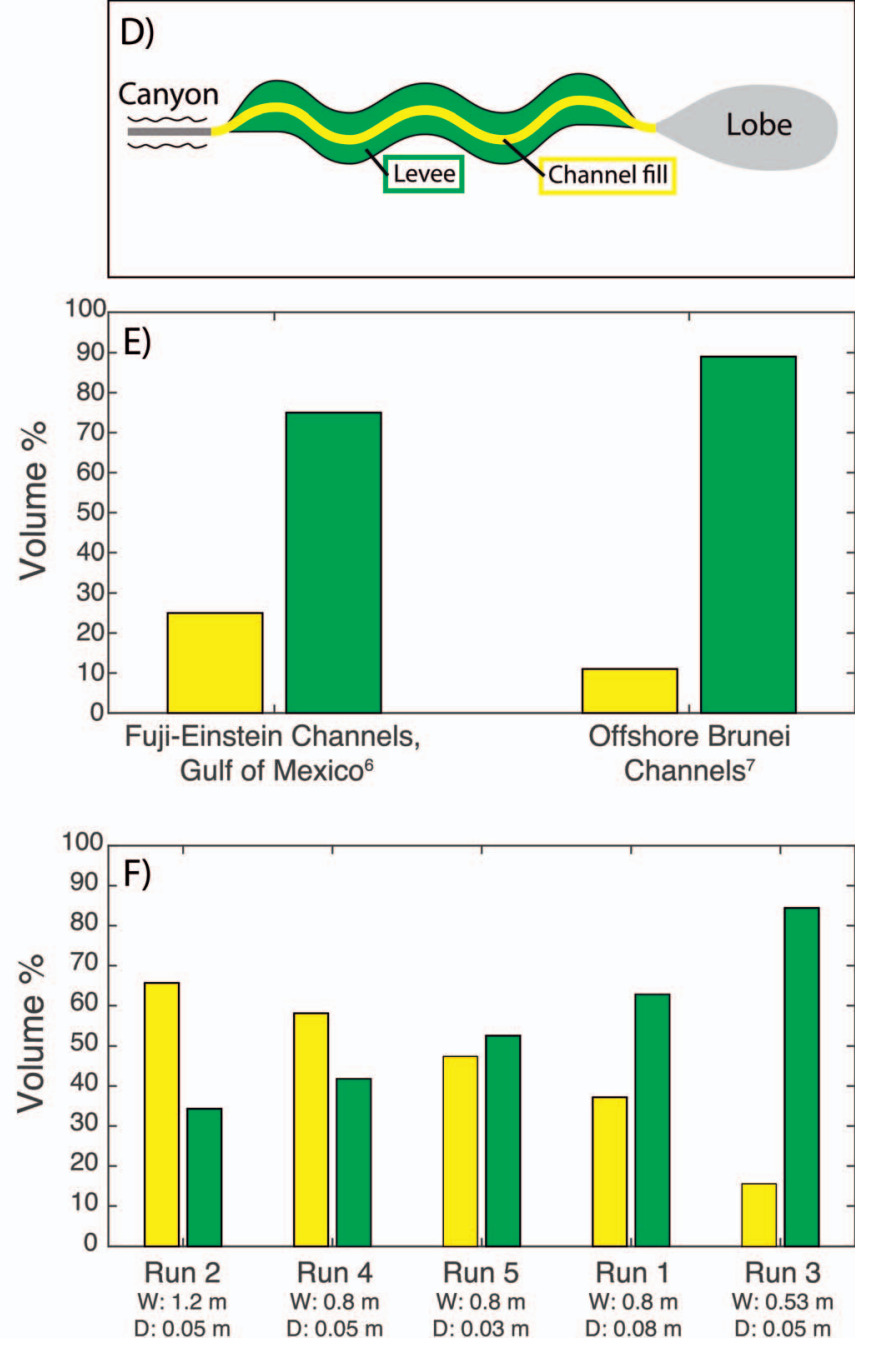

FIG. 15.-Volume partitioning in deep-water systems. A) Comparison I: partitioning between channel-related deposits (in blue) and lobe deposits (in red). Alternatively, we compare volume partitioning between slope (light blue) and the basin floor (pink) if this is the type of data available. B) Partitioning in natural systems between slope channels

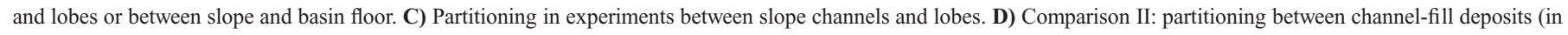

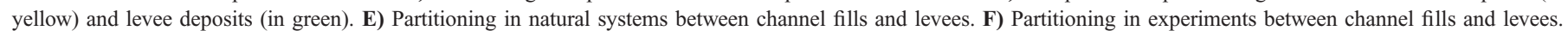
${ }^{1}$ Jegou et al. 2008 and Pirmez and Imran 2003; ${ }^{2}$ Paola and Martin 2012; ${ }^{3}$ Picot et al. 2016; ${ }^{4}$ Carvajal and Steel 2012; ${ }^{5}$ van der Merwe et al. 2014; ${ }^{6}$ Sylvester et al. 2012; ${ }^{7}$ Straub et al. 2012.

which means that the channel was very efficient (Fig. 15C). Thus, the experiments show that optimization of channel dimensions reduces channel-floor deposition more effectively than levee deposition. Some degree of current overspill onto levees will nearly always occur unless turbidity currents are confined in a deep canyon.

Grain-Size Partitioning.-Partitioning of sediment grain-size fractions between submarine slopes, where channel-levee systems dominate, and basin floors, where lobes dominate, has been documented for the LewisFox Hills Formation in the Washakie Basin (Carvajal and Steel 2012). Additionally, Prather et al. (2017) report sand percentages for the Miocene and Paleogene deep-water deposits in the Gulf of Mexico and for the Niger delta slope. In each of these cases the highest sand percentage is found on the basin floor (Fig. 16B). Similarly, other basin-wide studies have qualitatively shown that most of the sand transported by turbidity currents accumulates on the lower slope and basin floor (Hubbard et al. 2010; van der Merwe et al. 2014). The upper and middle Miocene deposits in the Gulf of Mexico show relatively little difference in sand percentage between the slope and basin floor. This is thought to be a result of the stepped slope profile that enhances capturing of sand in minibasins on the slope (Prather et al. 2017).

An increase in deposit grain size from the slope to the basin floor is also found in the experiments. The contrast in grain size is smaller than in natural systems (Fig. 16C), partially because the sediment available in the experiments is mostly of sand size whereas the range can be much broader in natural systems. Nevertheless, the comparison illustrates that the same patterns of grain-size partitioning are produced across a wide range of scales.

\section{CONCLUSIONS}

We conducted experiments in which turbidity currents flowed through different types of submarine channels. The results highlight that the functioning of channels as a sediment filter is strongly dependent on the channel dimensions. Results show that: 

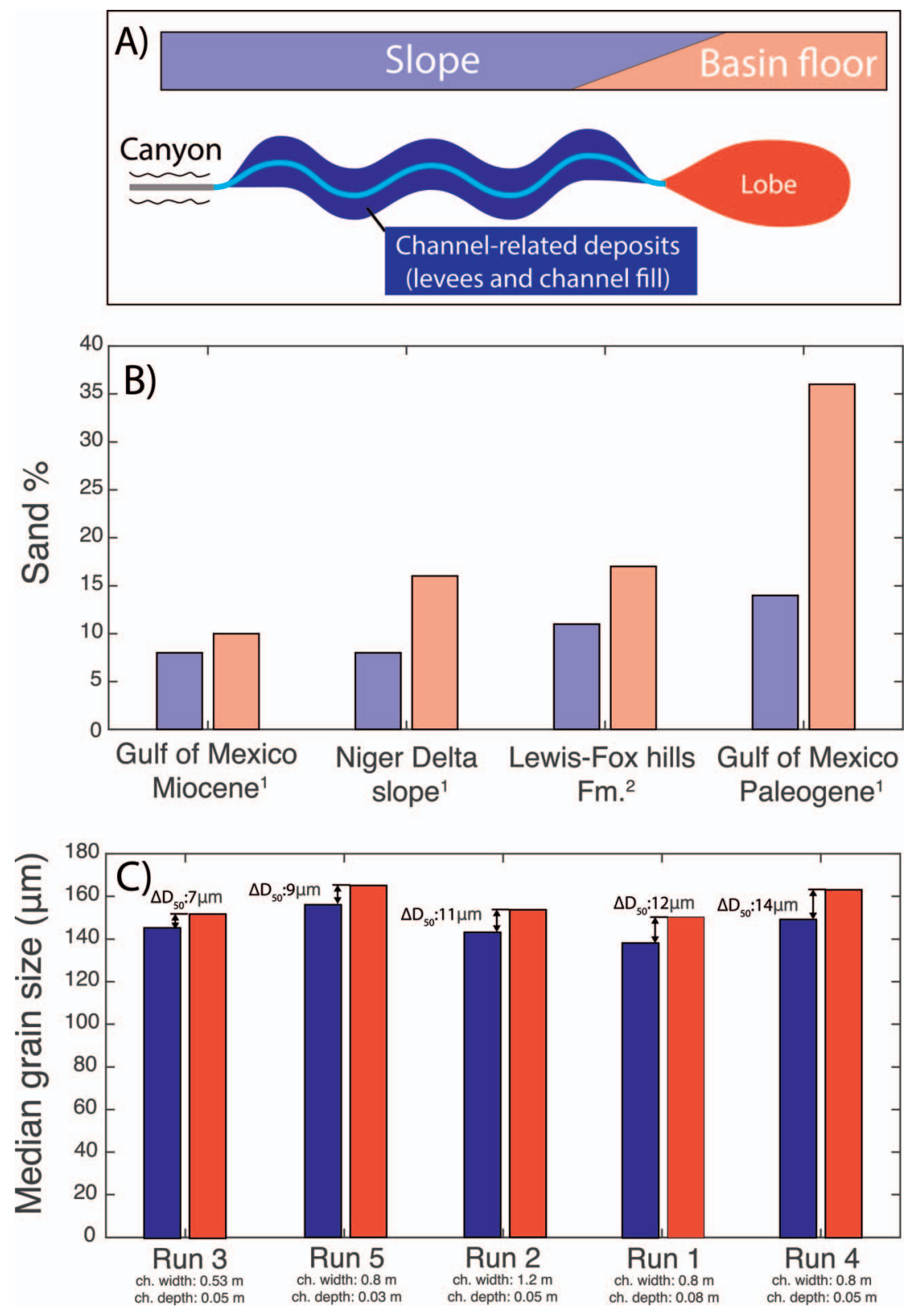

FIG. 16.- Grain-size partitioning in deep-water systems. A) Partitioning between channel-related deposits (in blue) and lobe deposits (in red). Alternatively, we compare volume partitioning between slope (light blue) and basin floor (pink), if this is the type of data available. B) Grain-size partitioning in natural systems between slope and basin-floor deposits. C) Grain-size partitioning in the experiments between channel-related deposits and levees. For these experiments, the volume of the channel-related deposits is equal to the deposit volume on the slope and the basin-floor volume is equal to the lobe volume. ${ }^{1}$ Prather et al. 2017; ${ }^{2}$ Carvajal and Steel 2012.
1. Channels with a large depth combined with a low W/D ratio show the highest degree of sediment bypass to the basin floor.

2. Channel depth relative to flow thickness is the main control on the amount of overspill and subsequent levee deposition. Channel widthto-depth ratio is the main control on the volume of deposition on the channel floor.

3. Similarly to most natural systems, the experiments show that slope deposits are fine-grained compared to the basin-floor deposits.

4. A mass-balance reconstruction, where deposits are subtracted from the initial sediment flux, shows that suspended-sediment volume in transport decrease downstream in the system due to preferential extraction of the coarse sediment fraction. The sediment that is extracted from the flow on the slope represents a finer part of the grain-size spectrum than the deposits on the lobe.

5. Experiments with various channel dimensions and sediment partitioning patterns are considered to be snapshots of different phases of channel evolution. An incipient channel has a small depth and width. This results in a low efficiency due to the large volume of overspill. A mature channel has a larger depth, and this results in a higher efficiency. A channel in the latest stage of its evolution has a large width and a small depth. This results in a low efficiency reflected in the large volume of deposition inside and outside the channel.

\section{ACKNOWLEDGMENTS}

Henk van der Meer and Thony van der Gon Netscher are thanked for technical assistance with the experiments. This is a contribution of the Eurotank Studies of Experimental Deepwater Sedimentology (EuroSEDS), financially supported by the Dutch Organisation for Scientific Research (NWO, grant no. 864.13.006), ExxonMobil, Shell, and Statoil. Reviews by Chris Paola and Bradford Prather and Associate Editor Morgan Sullivan greatly helped to improve the manuscript. 


\section{REFERENCES}

BaAs, J.H., McCaffrey, W.D., Haughton, P.D.W., and Choux, C., 2005, Coupling between suspended sediment distribution and turbulence structure in a laboratory turbidity current: Journal of Geophysical Research: Oceans, v. 110, p. 1-20.

Carvajal, C., and Steel, R., 2012, Source-to-sink sediment volumes within a tectonostratigraphic model for a Laramide shelf-to-deep-water basin: methods and results, in Busby, C., and Azor, A., eds., Tectonics of Sedimentary Basins: Recent Advances: Oxford, UK, Wiley-Blackwell, p. 131-151.

Clark, J.D., and Pickering, K.T., 1996, Architectural elements and growth patterns of submarine channels: application to hydrocarbon exploration: American Association of Petroleum Geologists, Bulletin, v. 80, p. 194-221

Covault, J.A., Shelef, E., Traer, M., Hubbard, S.M., Romans, B.W., and Fildani, A., 2012 , Deep-Water channel run-out length: insights from seafloor geomorphology: Journal of Sedimentary Research, v. 82, p. 21-36.

Damuth, J.E., And Kumar, N., 1975, Amazon Cone: morphology, sediments, age, and growth pattern: Geological Society of America, Bulletin, v. 86, p. 863-878.

de Leeuw, J., Eggenhuisen, J.T., and Cartigny, M.J.B., 2016, Morphodynamics of submarine channel inception revealed by new experimental approach: Nature Communications, v. 7, p. 1-7

De Leeuw, J., Eggenhuisen, J.T., and Cartigny, M.J.B., 2018, Linking submarine channellevee facies and architecture to flow structure of turbidity currents: insights from flume tank experiments: Sedimentology, v. 65, p. 931-951.

Dorrell, R.M., Darby, S.E., Peakall, J., Sumner, E.J., Parsons, D.R., and Wynn, R.B. 2014, The critical role of stratification in submarine channels: implications for channelization and long runout of flows: Journal of Geophysical Research: Oceans, v. 119 , p. $2620-2641$.

GARCIA, M.H., 1994, Depositional turbidity currents laden with poorly sorted sediment Journal of Hydraulic Engineering, v. 120, p. 1240-1263.

Hampson, G.J., Duller, R.A., Petter, A.L., Robinson, R.A.J., and Allen, P.A., 2014 Mass-balance constraints on stratigraphic interpretations of linked alluvial-coastalshelfal deposits from source to sink: example from the Cretaceous Western Interio Basin, Utah and Colorado, U.S.A.: Journal of Sedimentary Research, v. 84, p. 935-960.

Hansen, L.A.S., Callow, R.H.T., Kane, I.A., Gamberi, F., Rovere, M., Cronin, B.T., and KNELLER, B.C., 2015, Genesis and character of thin-bedded turbidites associated with submarine channels: Marine and Petroleum Geology, v. 67, p. 852-879.

HeEzen, B.C., AND Ewing, M., 1952, Turbidity currents and submarine slumps, and the 1929 Grand Banks earthquake: American Journal of Science, v. 250, p. 849-873.

Hiscott, R.N., Hall, F.R., And Pirmez, C., 1997, Turbidity-current overspill from the Amazon Channel: texture of the silt/sand load, paleoflow from anisotropy of magnetic susceptibility, and implications for flow processes: Proceedings of the Ocean Drilling Program, Scientific Results, v. 155 , p. 531-538.

Hodgson, D., Kane, I., Flint, S., Brunt, R., and Ortiz-Karpf, A., 2016, Time transgressive confinement on the slope and the progradation of basin-floor fans: implications for the sequence stratigraphy of deep-water deposits: Journal of Sedimentary Research, v. 86, p. $73-86$.

Hubbard, S.M., Fildani, A., Romans, B.W., Covault, J.A., and McHargue, T.R., 2010 High-relief slope clinoform development: insights from outcrop, Magallanes Basin, Chile: Journal of Sedimentary Research, v. 80, p. 357-375.

Hubbard, S.M., Covault, J.A., Fildani, A., and Romans, B.W., 2014, Sediment transfer and deposition in slope channels: deciphering the record of enigmatic deep-sea processes from outcrop: Geological Society of America, Bulletin, v. 126, p. 857-871.

Jegou, I., Savoye, B., Pirmez, C., And Droz, L., 2008, Channel-mouth lobe complex of the recent Amazon Fan: the missing piece: Marine Geology, v. 252, p. 62-77.

Jobe, Z., Sylvester, Z., Pittaluga, M.B., Frascati, A., and Pirmez, C., 2017, Facies architecture of submarine channel deposits on the western Niger Delta slope implications for grain-size and density stratification in turbidity currents: Journal of Geophysical Research: Earth Surface, v. 122, p. 473-491.

Kane, I.A., Kneller, B.C., Dykstra, M., Kassem, A., and McCaffrey, W.D., 2007, Anatomy of a submarine channel-levee: an example from Upper Cretaceous slope sediments, Rosario Formation, Baja California, Mexico: Marine and Petroleum Geology, v. 24 , p. $540-563$.

Kane, I.A., McCaffrey, W.D., and Peakall, J., 2008, Controls on sinuosity evolution within submarine channels: Geology, v. 36, p. 287-290.

Kneller, B., 2003, The influence of flow parameters on turbidite slope channel architecture: Marine and Petroleum Geology, v. 20, p. 901-910.

Kneller, B.C., Nasr-Azadani, M., Radhakrishnan, S., and Meiburg, E., 2016, Longrange sediment transport in the world's oceans by stably stratified turbidity currents: Journal of Geophysical Research: Oceans, v. 121, p. 8608-8620.

Krumbein, W.C., And Aberdeen, E., 1937, The sediments of Barataria Bay: Journal of Sedimentary Petrology, v. 7, p. 3-17.

Maier, K.L., Fildani, A., Paull, C.K., Mchargue, T.R., Graham, S.A., and Caress, D.W. 2013, Deep-sea channel evolution and stratigraphic architecture from inception to abandonment from high-resolution Autonomous Underwater Vehicle surveys offshore central California: Sedimentology, v. 60, p. 935-960.

Michael, N.A., Whittaker, A.C., Carter, A., and Allen, P.A., 2014, Volumetric budget and grain-size fractionation of a geological sediment routing system: Eocene Escanilla
Formation, south-central Pyrenees: Geological Society of America, Bulletin, v. 126, p. $585-599$.

Mohrig, D., And Buttles, J., 2007, Deep turbidity currents in shallow channels: Geology, v. 35 , p. $155-158$

Normark, W.R., 1978, Fan valleys, channels, and depositional lobes on modern submarine fans: characters for recognition of sandy turbidite environments: American Association of Petroleum Geologists, Bulletin, v. 62, p. 912-931.

Ortiz-Karpf, A., Hodgson, D.M., And McCAFfrey, W.D., 2015, The role of mass-transport complexes in controlling channel avulsion and the subsequent sediment dispersal patterns on an active margin: the Magdalena Fan, offshore Colombia: Marine and Petroleum Geology, v. 64 , p. $58-75$

Paola, C., And Martin, J.M., 2012, Mass-balance effects in depositional systems: Journal of Sedimentary Research, v. 82, p. 435-450.

Paola, C., Straub, K., Mohrig, D., and Reinhardt, L., 2009, The "unreasonable effectiveness" of stratigraphic and geomorphic experiments: Earth-Science Reviews, v. 97, p. $1-43$.

Pemberton, E.A.L., Hubbard, S.M., Fildani, A., Romans, B., And Stright, L., 2016, The stratigraphic expression of decreasing confinement along a deep-water sediment routing system: outcrop example from southern Chile: Geosphere, v. 12, p. 114-134.

Picot, M., Droz, L., Marsset, T., Dennielou, B., And Bez, M., 2016, Controls on turbidite sedimentation: insights from a quantitative approach of submarine channel and lobe architecture (late Quaternary Congo Fan): Marine and Petroleum Geology, v. 72, p. 423 446, doi: 10.1016/j.marpetgeo.2016.02.004.

Pirmez, C., And Imran, J., 2003, Reconstruction of turbidity currents in Amazon Channel: Marine and Petroleum Geology, v. 20, p. 823-849.

Posamentier, H.W., and Kolla, V., 2003, Seismic geomorphology and stratigraphy of depositional elements in deep-water settings: Journal of Sedimentary Research, v. 73, p. 367-388.

Prather, B.E., Pirmez, C., Sylvester, Z., and Prather, D.S., 2012, Stratigraphic response to evolving geomorphology in a submarine apron perched on the Upper Niger Delta Slope, in Prather, B.E., Deptuck, M.E., Mohrig, D.C., vanHoorn, B., and Wynn, R.B. eds., Application of the Principles of Seismic Geomorphology to Continental-Slope and Base-of-Slope Systems: Case Studies From Seafloor and Near-Seafloor Analogues: SEPM, Special Publication 99, p. 145-161.

Prather, B.E., O’Byrne, C., Pirmez, C., and Sylvester, Z., 2017, Sediment partitioning, continental slopes and base-of-slope systems: Basin Research, v. 29, p. 394-416.

Stevenson, C.J., Talling, P.J., Wynn, R.B., Masson, D.G., Hunt, J.E., Frenz, M., Akhmetzhanhov, A., And Cronin, B.T., 2013, The flows that left no trace: very largevolume turbidity currents that bypassed sediment through submarine channels without eroding the sea floor: Marine and Petroleum Geology, v. 41, p. 186-205.

Stevenson, C.J., Jackson, C.A.L., Hodgson, D.M., Hubbard, S.M., and Eggenhuisen, J.T., 2015, Deep-water sediment bypass: Journal of Sedimentary Research, v. 85, p. 1058 1081

Straub, K.M., And Mohrig, D., 2008, Quantifying the morphology and growth of levees in aggrading submarine channels: Journal of Geophysical Research: Earth Surface, v. 113, p. $1-20$.

Straub, K.M., Mohrig, D., And Pirmez, C., 2012, Architecture of an aggradational tributary submarine channel network on the continental slope offshore Brunei Darussalam, in Prather, B.E., Deptuck, M.E., Mohrig, D.C., vanHoorn, B., and Wynn, R.B., eds., Application of the Principles of Seismic Geomorphology to ContinentalSlope and Base-of-Slope Systems: Case Studies From Seafloor and Near-Seafloor Analogues: SEPM, Special Publication 99, p. 145-161.

Strong, N., Sheets, B., Hickson, T., and Paola, C., 2005, A mass-balance framework for quantifying downstream changes in fluvial architecture, in Blum, M.D., Marriott, S.B. and Leclair, S.F., eds., Fluvial Sedimentology VII: International Association of Sedimentologists, Special Publication 35, p. 243-253.

Sylvester, Z., Deptuck, M.E., Prather, B.E., Pirmez, C., and O'Byrne, C., 2012, Seismic stratigraphy of a shelf-edge delta and linked submarine channels in the northeastern Gulf of Mexico, in Prather, B.E., Deptuck, M.E., Mohrig, D.C., vanHoorn, B., and Wynn, R.B., eds., Application of the Principles of Seismic Geomorphology to ContinentalSlope and Base-of-Slope Systems: Case Studies From Seafloor and Near-Seafloor Analogues: SEPM, Special Publication 99, p. 145-161.

Symons, W.O., Sumner, E.J., Paull, C.K., Cartigny, M.J.B., Xu, J.P., Maier, K.L., Lorenson, T.D., And TALLing, P.J., 2017, A new model for turbidity current behavior based on integration of flow monitoring and precision coring in a submarine canyon: Geology, v. 45, p. G38764.1.

Talling, P.J., Masson, D.G., Sumner, E.J., and Malgesini, G., 2012, Subaqueous sediment density flows: depositional processes and deposit types: Sedimentology, v. 59, p. 1937 2003

van der Merwe, W.C., Hodgson, D.M., Brunt, R.L., and Flint, S.S., 2014, Depositional architecture of sand-attached and sand-detached channel-lobe transition zones on an exhumed stepped slope mapped over a $2500 \mathrm{~km}^{2}$ area: Geosphere, v. 10, p. 1076-1093.

Received 2 November 2017; accepted 26 April 2018. 
Slope deposit volumes

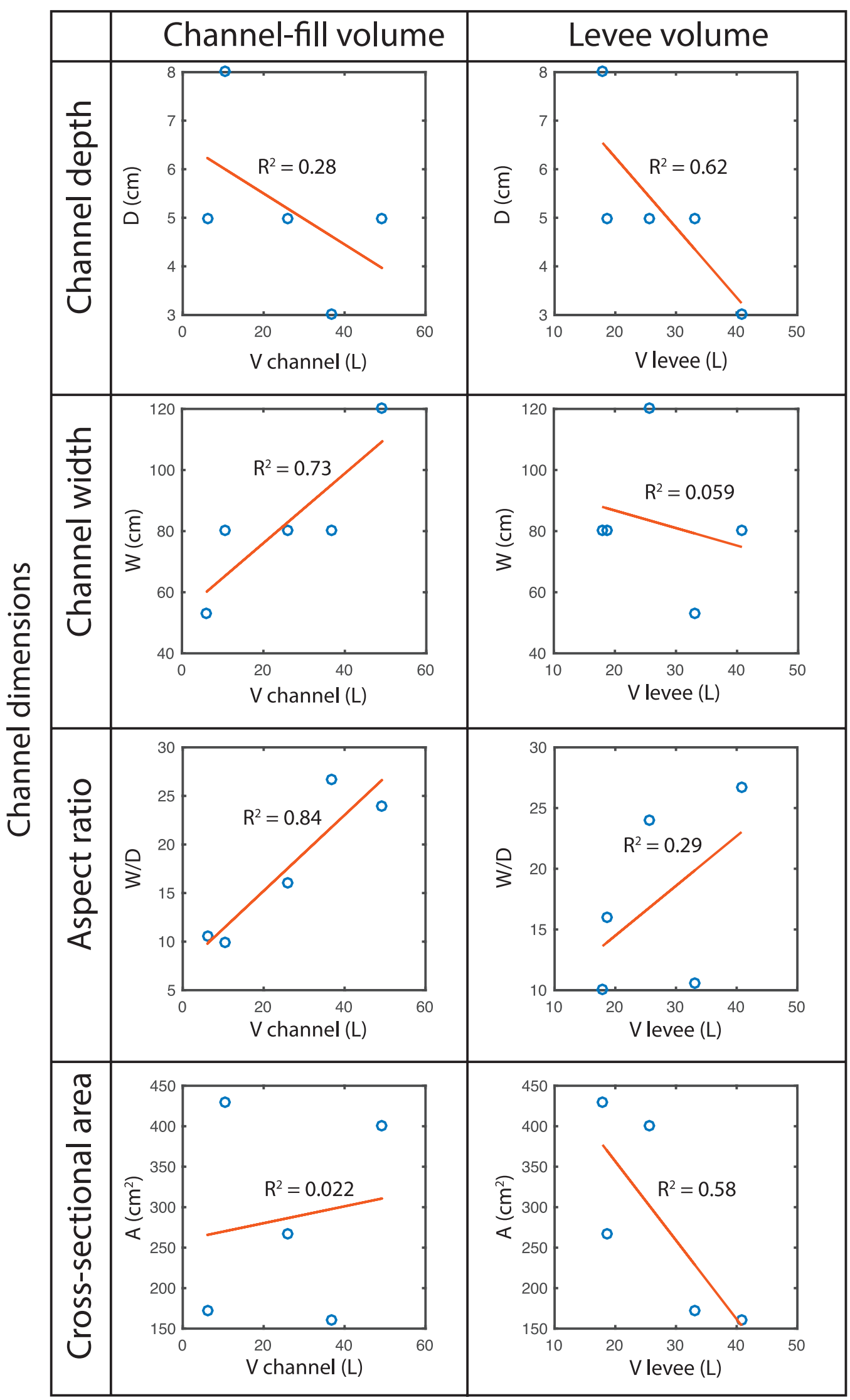

APPENDIX.-Correlation between channel dimensions (width, depth, D/W, and area) and slope-deposit volumes (levees and lobes). Correlation coefficients ( $\left.\mathrm{R}^{2}\right)$ are shown in each plot. 